\title{
MiRNAs at the Crossroads between Innate Immunity and Cancer: Focus on Macrophages
}

\author{
Graziella Curtale \\ Department of Immunology and Microbiology, the Scripps Research Institute, Jupiter, 33458 FL, USA; \\ gcurtale@gmail.com; Tel./Fax: +1-561-228-2372
}

Received: 27 December 2017; Accepted: 6 February 2018; Published: 8 February 2018

\begin{abstract}
Innate immune cells form an integrative component of the tumor microenvironment (TME), which can control or prevent tumor initiation and progression, due to the simultaneous processing of both anti- and pro-growth signals. This decision-making process is a consequence of gene expression changes, which are in part dependent on post-transcriptional regulatory mechanisms. In this context, microRNAs have been shown to regulate both recruitment and activation of specific tumor-associated immune cells in the TME. This review aims to describe the most important microRNAs that target cancer-related innate immune pathways. The role of exosomal microRNAs in tumor progression and microRNA-based therapeutic strategies are also discussed.
\end{abstract}

Keywords: microRNA; inflammation; cancer; macrophages

\section{Introduction}

In the last decade, local immune response has emerged as key factor in the modulation of the multistep process of cancer progression (reviewed in [1,2]). Innate and adaptive immune cells not only infiltrate tumors themselves, but also the tumor milieu. The highly heterogeneous tumor microenvironment (TME) consists of fibroblasts, immune cells, endothelial cell progenitors, extracellular matrix components, blood, and lymphatic vessels (reviewed in $[3,4]$ ). Altogether, these different cell types contribute to tumor initiation and progression, by regulating a fine balance between anti- and pro-growth signals. Indeed, the immune system and tumor cells constantly engage each other in a dynamic process that can have synergistic or opposite outcomes. These include eradication of the tumor, according to the "tumor surveillance hypothesis", coined by Burnet and Thomas in 1957 [5-7], or the escape of tumor from immune recognition [1,8]. Evidence supporting the involvement of the immune system in the recognition and eradication of developing tumors was provided by in vivo experiments on immunodeficient mice, including $\operatorname{Rag}^{-/-}, \mathrm{IFN} \gamma^{-/-}$or $\mathrm{Prf}^{-/-}$genetic backgrounds [9-13]. These studies showed higher incidence of spontaneous and carcinogen-induced solid tumors as well as an increased incidence of lymphomas [13]. However, cancer cells can also generate their own immunosuppressive microenvironment that can be traced to the transcriptional regulatory level [14].

In this review we will focus on the role of miRNAs as molecular determinants in tumor progression and macrophage-mediated immune surveillance.

\subsection{MiRNA Biogenesis and Maturation: A Brief Overview}

MicroRNAs (miRNAs) are small noncoding RNAs endogenously expressed in almost all eukaryotes, and are considered major epigenetic factors in post-transcriptional regulation of gene expression [15-18]. These 20-2 nucleotide (nt) molecules are mainly transcribed by RNA polymerase II as primary miRNA transcripts, termed pri-miRNAs $[19,20]$. They are then subjected to an extensive processing in the nucleus as substrates of a large protein complex called the microprocessor, that includes the RNAse III enzyme Drosha and its partner DiGeorge syndrome critical region 8 (DGCR8) [16,21-23]. 
This first maturation step transforms pri-miRNA into stem-loop-structured miRNA precursors (pre-miRNAs), which are then exported to the cytoplasm through the Exportin 5 (Xpo5) system [21,24,25]. There, another RNAse III protein, called Dicer, cuts pre-miRNA molecules into mature miRNAs [16,21,26]. Suitably processed, mature miRNA molecules are finally incorporated into the RNA-induced silencing complex (RISC) [27,28]. The core component of RISC is a member of the Ago protein family (most commonly Ago2), which brings together the templating miRNA and its target mRNA [16,29]. miRNA-loaded RISC specifically recognizes short sequences of 6-7 nt, located in the $3^{\prime}$ untranslated region (UTR) of target mRNAs, that are complementary to the so-called "seed region", located in the $5^{\prime}$ end of the miRNA molecule [30-32]. MiRNAs can either induce mRNA degradation or inhibition of translation, depending on the degree of complementarity between the $3^{\prime}$ UTR and the seed region $[31,33,34]$.

\subsection{Dysregulation of miRNA Expression and Biogenesis in Cancer}

It has been estimated that approximately $30-60 \%$ of human protein-coding genes are regulated by miRNAs [35-40]. MiRNAs participate in modulating several biological processes, including differentiation, apoptosis, cell cycle, proliferation, and the immune response [41,42]. Alterations in miRNA expression profile have been associated with several diseases, including cancer [43-46].

Deregulated miRNA expression favors acquisition of cancer hallmarks as well as affects the tumor microenvironment, leading to development and progression of tumor.

Both genetic and epigenetic mechanisms have been involved in miRNA expression deregulation in cancer; including amplification or deletion of miRNA genes, acetylation and methylation of miRNA promoter, aberrant transcriptional control and defects in the miRNA biogenesis machinery [47-49] (Figure 1).

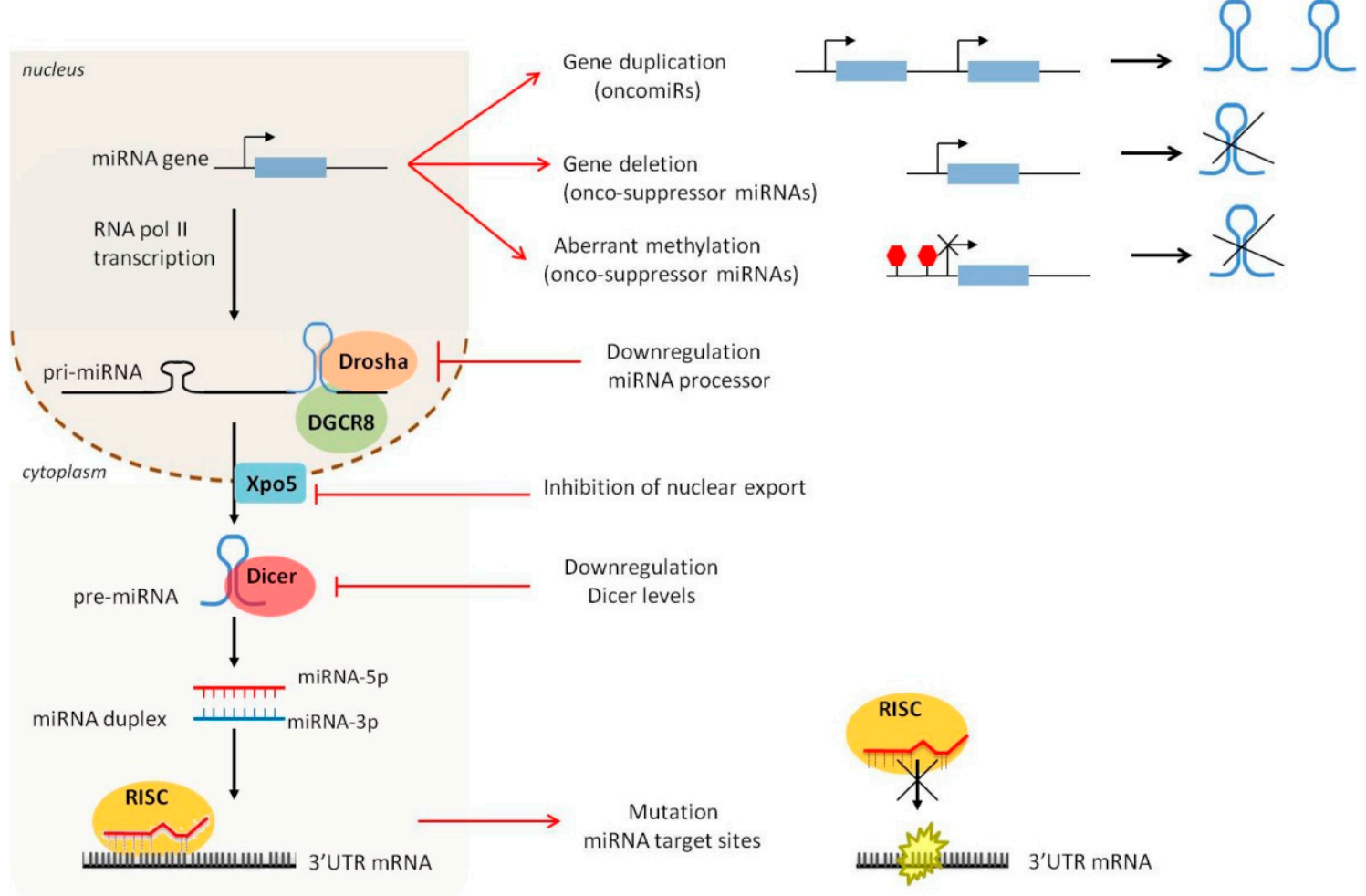

Figure 1. Deregulation of microRNA (miRNA) biogenesis during cancer initiation and progression.

During cancer initiation and progression, deregulation of miRNA expression can occur at different steps of miRNA biogenesis. Gene duplication of the miRNA promoter can lead to enhanced 
transcription of the pri-miRNA molecule. Aberrant methylation of the miRNA promoter, and reduced expression of factors involved in miRNA processing and mutation of the seed site in the $3^{\prime}$ UTR of mRNA targets can abrogate miRNA maturation or functional activity.

\subsubsection{Amplification and Deletion of miRNA Genes}

More than $50 \%$ of miRNA genes are located in fragile sites or cancer-associated genomic regions $[47,50]$. The first study of altered miRNA expression in cancer showed that miR-15 and miR-16, targeting the anti-apoptotic factor B cell lymphoma 2 (BCL2), are located at a chromosomal region (13q14), frequently deleted in the majority of chronic lymphocytic leukemia (CLL) cases [50]. Since then, other studies in both human and mice cells demonstrated the association between genomic location of miRNA and cancer susceptibility [50,51]. In 2010, Lagana et al. investigated the location of more than 700 miRNA loci at chromosomal fragile sites and found that $44 \%$ of them were located in genomic regions frequently translocated in cancer. The most frequent deleted miRNAs were the miR-204 and the let-7 family, both reported as onco-suppressor miRNAs [52-54].

\subsubsection{Epigenetic Alterations}

miRNA loci are frequently amplified or deleted in concert with epigenetic alterations. In some cases they show aberrant epigenetic marks, such as DNA hypo/hypermethylation and hypo/hyperacetylation at the promoter of miRNAs, or repressive histone marks, that lead to the silencing of the miRNA gene [55-59] (Figure 1). Genome-wide screening studies in cancer cells identified specific epigenetic patterns associated with active or repressed miRNA promoter. In particular, tri-methylation of histone H3 lysine 4 (H3K4me3) and acetylation of histone H3 lysine 9 or 14 (H3K9ac and H3K14ac, respectively) are hallmarks of active miRNA gene promoters. By contrast, H3K9me2, H3K9me3 and H3K27me3 are marks of repression $[33,43]$. The characterization of specific epigenetic marks on miRNA promoters enabled the identification of epigenetically dysregulated miRNAs in both solid and hematological malignancies [60,61].

Aberrant DNA methylation is another frequent epigenetic mechanism of miRNA gene silencing. In normal cells, the $\mathrm{CpG}$ island is unmethylated and the chromatin is associated with active histone modifications (H3K4me3, H3K3me2, H3K9ac and H3K14ac). In cancer cells, miRNAs that exert a tumor suppressor function are downregulated via $\mathrm{CpG}$ island hypermethylation of the corresponding gene, while miRNAs with a pro-tumoral activity are often upregulated via hypomethylation of their $\mathrm{CpG}$ island. For instance, hypermethylation of $\mathrm{CpG}$ island at the promoter of members of the miR-34 gene family (miR-34a, miR-34b, and miR-34c), frequently occurs in multiple cancer types, refs. $[55,61]$ and the aberrant methylation of miR-34 has also been associated with increased frequency of cancer metastasis and invasion [16,31]. Another miRNA epigenetically silenced in both solid and hematological malignancies is the miR-124 family (miR-124-1, miR-124-2, and miR-124-3), a tumor suppressor miRNA, which targets RAC1 and cyclin-dependent kinase 6 (CDK6) [47,48,62,63]. Its reduced expression in all patients results in the activation of CDK6 and the phosphorylation of retinoblastoma $(\mathrm{Rb})$ protein [44].

\subsubsection{Defects in the miRNA Biogenesis Pathway}

Downregulation of enzymes and cofactors involved in the miRNA maturation process can also lead to dysregulated miRNA expression in cancer cells. Evidence reported in the last decade demonstrates that many proteins involved in miRNA processing function as haplo-insufficient tumor suppressors. For instance, mutations of Xpo5 that trap miRNA transcripts in the nucleus correlate with carcinomas characterized by microsatellite instability $[64,65]$. Similarly, partial deletions of Dicer1 and Drosha have been shown to promote tumorigenesis in vitro and in vivo [62,66]. Moreover, recent findings demonstrated that two subunits of the microprocessor: the DEAD-box RNA helicase p68 (DDX5) and p72 (DDX17), required for the recruitment of the microprocessor to some pri-miRNAs, are also substrates of the tumor suppressor p53 [67]. In response to DNA damage, p53 interacts 
with p68 and enhances the post-transcriptional maturation of miRNAs with growth-suppressive function $[67,68]$. Conversely, mutant versions of p53 have been shown to inhibit post-transcriptionally the maturation of a subset of onco-suppressor miRNAs, by sequestering the RNA helicase p72/82 from the microprocessor complex [68]. These findings suggest that $\mathrm{p} 53$ governs a tumor suppressive program that affects miRNA biogenesis in a transcription-independent fashion.

\subsubsection{Mutations of miRNA Target Genes}

A few studies also reported genetic alterations in miRNA target sites in the $3^{\prime}$ UTR of onco-suppressor genes [69,70]. In particular, two different papers published in 2007 described the presence of chromosomal rearrangements at the $3^{\prime}$ UTR of the HMGA2 locus, resulting in the escape of HMGA2 from let-7 regulation and the consequent promotion of tumor formation [70,71]. Additionally, a clinical study of 87 non-small cell lung cancer patients published by Chin et al. [72] identified a single nucleotide polymorphism (SNP) in the $3^{\prime} \mathrm{UTR}$ of the KRAS oncogene. This variant allele caused the disruption of let-7e-mediated regulation of KRAS and the consequent upregulation of KRAS expression correlating with increased cancer risk [72].

\section{Role of miRNAs in Macrophage Polarization}

Macrophages are key players at the interface between innate and adaptive immunity, acting as antigen-presenting cells, phagocytes and able to promote inflammation and also its resolution through differentiated immune lineages. One of the most remarkable characteristics of macrophages is their plasticity and heterogeneity. According to their responsiveness to specific environmental cues, they are generally classified into two main types: M1 (classically activated) and M2 (alternatively activated) macrophages, with each displaying a characteristic gene expression profile and functional phenotype. M1-polarized macrophages are potent antimicrobial effector cells, specialized in the defense against intracellular pathogens. They are responsive to pro-inflammatory stimuli like interferon- $\gamma$ (IFN $\gamma$ ) and lipopolysaccharide (LPS). Both IFN $\gamma$ - and LPS-mediated activation of TLR4 converge on the activation of: nuclear factor kappa-B (NF- $\mathrm{kB}$ ), activator protein 1 (AP-1) and activator of transcription 1 (STAT1), leading to the release of pro-inflammatory cytokines (i.e., TNF $\alpha$, IL-12, IL-1, IL-6) and chemokines (i.e., chemokine (C-C motif) ligand 2, CCL2, chemokine (C-X-C motif) ligand 10, CXCL10). By contrast, M2-polarized macrophages are specialized in defending against extracellular pathogens and are induced by a broader range of stimuli, including IL-4, IL-10, IL-13, and glucocorticoids. M2 macrophages are reviewed in [73] (Table 1).

Several studies have profiled the expression of miRNAs in M1- and M2-polarized human and murine macrophages, by using microarray and quantitative polymerase chain reaction (qPCR) techniques. A report published in 2013 by Zhang et al. [74] showed the expression profile of murine bone marrow-derived macrophages (BMdM), identifying 109 miRNAs differentially expressed between M1- and M2-polarized conditions. More specifically, miR-155, miR-181 and miR-451 were significantly upregulated in M1 macrophages, whereas miR-125a-5p, miR-146a, miR-145-5p, miR-143-3p were more highly expressed in M2 macrophages. Later studies confirmed the upregulation of miR-155 in classically activated macrophages and the increased expression of miR-146a, miR-125b-5p and miR-127 in M2 macrophages [75]. Other miRNAs associated to M2 polarization were also identified; in particular miR-223 and let-7c [76].

miR-155 is one of the first miRNAs characterized as involved in both innate and adaptive immunity [77-80]. It plays a central role in the acquisition and modulation of M1/M2 profile, as it affects the expression of several genes important for the immune balance. miR-155 directly targets the expression of the IL-13 receptor $\alpha 1$ (IL13R $\alpha 1$ ), thereby inhibiting STAT6 activation and promoting $\mathrm{M} 1$ polarization [81]. Genes related to M2/pro-Th2 phenotype in macrophages indirectly regulated by miR-155 include CCL18, SERPINE, CD23 and DC-SIGN [81]. 
Table 1. MiRNAs expressed in myeloid cells having an impact on tumorigenesis. MiRNAs having a role in macrophage polarization, tumor invasion and immunosuppression are here listed ( $\uparrow=$ increased; $\downarrow=$ decreased).

\begin{tabular}{|c|c|c|c|c|}
\hline miRNA & Expression & Targets & Phenotype & \\
\hline miR-155 & $\uparrow$ M1 macrophages & C/EBP $\beta$, SHIP1, IL13R $\alpha 1$, SMAD2/3 & $\begin{array}{c}\text { Reprograms pro-tumoral M2/TAM } \\
\text { macrophages to M1 } \\
\text { pro-inflammatory macrophages }\end{array}$ & \multirow{6}{*}{ Macrophage Polarization } \\
\hline miR-125b & $\uparrow$ M1 macrophages & IRF4 & $\uparrow$ responsiveness to IFN $\gamma \uparrow$ tumor killing & \\
\hline miR-127 & $\uparrow$ in M2 macrophages $\downarrow$ by inflammation & DUSP1 & $\uparrow$ M1- and $\downarrow$ M2-related genes & \\
\hline miR-146a & $\uparrow$ M2 macrophages & NOTCH1, INHBA, PPAR $\gamma$, & $\begin{array}{c}\uparrow \mathrm{M} 2 \text { polarization and inflammation } \\
\qquad \mathrm{M} 1 \text { polarization }\end{array}$ & \\
\hline $\operatorname{miR}-223$ & $\downarrow$ TAM & IL1 $\beta$, IL-6 & $\uparrow \mathrm{M} 2$ polarization & \\
\hline let-7c & $\uparrow$ in M2 macrophages $\downarrow$ by inflammation & C/EBPס, PAK1 & $\uparrow$ M2- and $\downarrow$ M1-related genes & \\
\hline miR-511-3p & $\uparrow \mathrm{TAM}$ & ROCK2 & $\begin{array}{c}\downarrow \text { pro-tumoral gene signature of TAMS and } \\
\qquad \downarrow \text { tumor growth }\end{array}$ & \multirow{2}{*}{ Tumor invasion } \\
\hline miR-155 & $\uparrow$ M1 macrophages & SHIP1 & $\begin{array}{l}\uparrow \text { anti-tumor immunity. MiR-155 KO myeloid } \\
\text { cells induce faster tumor growth }\end{array}$ & \\
\hline miR-155 & $\uparrow$ MDSC & SOCS1 & $\begin{array}{l}\text { Required for tumor growth and the generation } \\
\text { of } \mathrm{CD} 4^{+} \text {Treg cells. MiR- } 155 \mathrm{KO} \text { mice are } \\
\text { resistant to carcinogenesis }\end{array}$ & \multirow{7}{*}{ Immune suppression (MDSC) } \\
\hline $\operatorname{miR}-494$ & $\uparrow$ MDSC & PTEN & $\begin{array}{l}\text { Regulates cell cycle progression; it induces arrest } \\
\text { in } \mathrm{G} 2 / \mathrm{M} \text { and increased inflammation }\end{array}$ & \\
\hline miR-20a & $\uparrow$ MDSC & STAT3 & $\begin{array}{l}\downarrow \text { MDSC-dependent suppression of } \mathrm{CD}^{+} \text {and } \\
\text { CD } 8^{+} \mathrm{T} \text { cell response }\end{array}$ & \\
\hline miR-223 & $\downarrow$ MDSC & $\mathrm{MEF} 2 \mathrm{C}$ & $\begin{array}{l}\text { Suppresses differentiation of tumor induced- } \\
\text { CD11bGr1+MDSC }\end{array}$ & \\
\hline miR-21 & $\uparrow$ MDSC & SHIP1 & $\uparrow$ proliferation and survival & \\
\hline $\operatorname{miR}-690$ & $\uparrow \mathrm{MDSC}$ & $\mathrm{C} / \mathrm{EBP} \alpha$ & $\begin{array}{c}\uparrow \text { MDSC expansion and proliferation } \\
\downarrow \text { terminal differentiation }\end{array}$ & \\
\hline miR-17-5p & $\uparrow \mathrm{MDSC}$ & STAT3 & $\begin{array}{l}\downarrow \text { MDSC ability to suppress Ag-specific CD4 } 4^{+} \\
\text {and } \mathrm{CD}^{+} \text {T cell response }\end{array}$ & \\
\hline
\end{tabular}


Other miRNAs that promote M1 polarization are miR-125b and miR-127. Taganov et al. demonstrated that miR-125b overexpression enhanced responsiveness to IFN $\gamma$, through the targeting of IRF4 and increased expression of pro-inflammatory cytokines [82]. These alterations in cell signaling and gene expression also resulted in increased killing of EL4 tumor cells both in vitro and in vivo [82].

Promotion of the M1 phenotype by miR-127 is mechanistically related to the inhibition of Bcl6 expression, which inhibits the phosphatase Dusp1. Reduction of Dusp1 levels lead to increased phosphorylation of JNK and the consequent induction of the inflammatory response. Accordingly, knockdown of miR-127 suppressed the expression of M1 signature genes and promoted the transcription of M2-related genes [83].

One of the first miRNA showing anti-inflammatory properties associated with M2 polarization is miR-146a. Transfection of peritoneal macrophages with miR-146a reduced the expression of M1 phenotype markers (e.g., iNOs, CD86, TNF $\alpha$, IL-12 and IL-6), and increased the production of M2 marker genes (e.g., Arg1, CCL17, CCL22 and CD206) [84]. Mechanistically, miR-146a promotes M2 polarization at least in part by targeting Notch1, PPAR $\gamma$ and inhibin $\beta$ A subunit of activin A (INHBA) [84,85].

miR-223 and let-7c have been shown to initiate M2 polarization in murine RAW264.7 macrophages. Enforced expression of miR-223 lead to the inhibition of LPS-dependent release of IL-1 $\beta$ and IL-6 [86]. Similarly, overexpression of let-7c reduced the expression of M1-related genes (i.e., iNOS and IL-12) and increased levels of M2 markers (i.e., FR- $\beta$ ), via targeting of C/EBP- $\delta$ [87] and PAK1 [88].

\section{The Fine Balance of the Innate Immune Tumor Response}

While the importance of adaptive immunity in tumor surveillance is recognized, the role of innate immune cells in this context has been subject to extensive debate. Evidence demonstrates that innate immune response can be critical in tumor prevention, but also in its initiation and progression. The final outcome of pro- versus anti-tumoral innate immune response is dependent on the TME, which first primes and then reinforces the differentiation and response of leukocytes recruited or already present in situ. Tumor milieu composition is not static, but dynamically evolves with tumor progression to promote growth and metastatic potential of cancer cells. Increasing evidence indicates that the majority of solid tumors are strictly linked to a chronic inflammation that reciprocally affects the cellular and molecular composition of the TME. Chronic inflammation is induced by pro-inflammatory mediators, released by myeloid cells. During the first stages of tumor formation, pro-inflammatory macrophages (e.g., M1 macrophages) represent the predominant type of myeloid cells involved. M1 macrophages not only release pro-inflammatory mediators, but are also characterized by increased phagocytic ability [89]. However, chronic inflammation can create a mutagenic microenvironment, causing genomic instability in the cells present. Due to this genetic instability, cancer cells acquire features that render them resistant to pro-inflammatory immune response and able to evade tumor immunosurveillance, promoting M2 macrophages for that purpose [90,91]. An example of an immune escape mechanism exploited by cancer is the upregulation of CD47 expression on tumor cells of patients affected by myeloid leukemia. CD47 is a pentaspanin, ubiquitously expressed on mammalian tissues, also known as integrin-associated protein (IAP) [92]. The engagement of CD47 with signal regulatory protein alpha (SIRP $\alpha$ ) expressed on macrophages, leads to inhibition and evasion of phagocytosis [93-95].

A second step in cancer progression is the infiltration of malignant tumors by pro-tumor macrophages: a heterogeneous population predominantly composed by tumor-associated macrophages (TAMs) and myeloid-derived suppressor cells (MDSCs). They both play a critical role in malignancy by promoting tumor growth, angiogenesis, and lymph node metastasis [96]. The dual role of macrophages in both preventing and promoting cancer progression reflects the complexity of the innate immune system in tumor development. Emerging evidence shows that this is apparent dualism is not due to recruitment of distinct differentiated cell types, but is rather from the result of extracellular stimuli as well as genetic and epigenetic changes that dynamically shape the innate immune cells [97]. Quality and duration of the innate immune response will ultimately dictate the fate of cancer development and the 
consequent clinical prognosis. In this context, the molecular mechanisms of crosstalk between cancer and immune cells are object of extensive studies and still remain to be extensively elucidated.

\section{4. miRNAs Involved in Tumor Immunosurveillance}

Tumor immunosurveillance is a well-established mechanism for regulation of tumor growth. In this regard, most studies have focused on the role of T- and NK-cells as critical immune effector cells (reviewed in: [98-100]). However, TAM play a major role in the recognition and clearance of foreign and damaged cells. They can infiltrate solid tumors and modulate $\mathrm{T}$ cell activity within the TME [101-104]. The general consensus is that TAM are usually pro-tumorigenic [105]. They are recruited by tumor-derived chemokines and produce low levels of inflammatory cytokines, promote Th2-T cell response, favor wound healing, and increase angiogenesis and metastases [106-108].

MDSCs are among the major myeloid cells responsible for cancer immune evasion [109]. They represent a heterogenic population of immature myeloid cell progenitors, macrophage precursors, granulocytes and dendritic cells (reviewed in $[110,111]$ ). They can promote tumor growth by enhancing angiogenesis or suppressing innate and adaptive immune responses [112-114]. In particular, MDSCs suppress T-cell responses by secretion of immune modulatory factors [75,115], restriction of $\mathrm{T}$ cell homing [116], induction of Tregs [117], suppression of NK cell cytotoxicity [118,119], promotion of M2 macrophage differentiation [120], and modulation of the priming activity of mature dendritic cells. Although TAMs and MDSCs are often regarded as separate entities, they share many characteristics in terms of gene expression profile [121]. For instance, they both require CCL2/CCR2 signaling for their recruitment to tissue sites [122,123]. Extensive studies provided evidence relative to aberrant expansion and accumulation of MDSCs in tumor models, and the molecular mechanism involved has started to be elucidated [124-126].

Recently, miRNAs have been identified as important determinants of TAM pro-tumoral activity as well as for the accumulation, expansion and tumor promoting function of MDSCs. A paradigmatic example is represented by miR-155, which mediates the antitumor potential of myeloid cells in early stages of breast cancer carcinogenesis [87]. miR-155 knockdown in myeloid cells induces faster tumor growth, reduction of M1-macrophages and enrichment of pro-tumor cytokines within tumor milieu. The proposed molecular mechanism to explain the observed phenotype involves the regulation of SHIP1, a major negative regulator of the pro-inflammatory PI3K/AKT pathway. The inhibition of this pathway was demonstrated to revert the common pro-inflammatory and pro-tumor events mediated by AKT activation [77,127]. miR-155 is also fundamental in the recruitment of MDSCs to the tumor site. In particular, it has been recently demonstrated to mediate the recruitment of MDSCs in glioma [128]. Similarly, miR-494, whose expression is induced by tumor-derived factors, enhances CXCR4-mediated chemotaxis of MDSCs and also modulates the intrinsic apoptotic pathway by targeting phosphatase and tensin homolog (PTEN) [82]. This results in increased activity of the Akt1 pathway and upregulation of MMPs, involved in tumor invasion and metastasis [82,129]. Other miRNAs such as miR-223, miR-21, and miR-690, have been recently described as important factors that affect differentiation and functional activity of MDSCs [130,131]. miR-223 is largely expressed in myeloid cells and downregulated in tumor associated MDSCs. It was first characterized as negative modulators of granulocytes differentiation and activation [132], and then demonstrated to suppress differentiation of tumor-induced CD11 $\mathrm{b}^{+} \mathrm{Gr} 1^{+}$MDSC [133]. miR-21 is upregulated in bone marrow-derived and splenic MDSCs. It regulates STAT3 activation by targeting phosphatase and tensin homolog (PTEN) protein [134]. miR-690 is upregulated in EL-4 tumor-elicited MDSCs. A study published in 2013 by Hedge et al. demonstrated that miR-690 maintains MDSCs at their immature immunosuppressive state by targeting $\mathrm{CEBP} / \alpha$, a transcription factor involved in cell cycle progression and terminal differentiation of myeloid cells [135]. 


\section{TAM-Derived miRNAs in Cancer-Related Inflammation}

Inflammation has been defined in 2009 as a hallmark of cancer [136]. Chronic and persistent inflammation can predispose cells to carcinogenesis and contribute to cancer development. Cancer-associated inflammation is characterized by the presence of infiltrating leukocytes, cytokines, chemokines, matrix-degrading enzymes and growth factors. This persistent inflammatory state can be initiated by microbial, viral or parasitic infection, and is responsible for the pathogenesis of about $15-20 \%$ of human tumors [137]. However, even tumors that are not epidemiologically linked to pathogens are characterized as having inflammatory infiltrates. Two general molecular pathways have been proposed to describe the interaction between inflammation and cancer: the intrinsic and the extrinsic pathways (reviewed in $[131,137,138]$ ). The intrinsic pathway consists of a series of genetic events (e.g., activation of oncogenes, inactivation of tumor suppressor genes) leading to neoplastic transformation that initiates inflammation-related programs. In the extrinsic pathway, tumor-infiltrating leukocytes, in particular macrophages, establish a state of chronic inflammation. Thus, both pathways converge in the activation of pro-inflammatory transcription factors in cancer cells and in the subsequent production of inflammatory mediators (i.e., cytokines, chemokines and prostaglandins) [139]. Evidence suggests that the inflammatory microenvironment so created further induces genetic instability in developing tumor cells, and promotes further infiltration by resident immune cells such as macrophages [139,140], MDSCs [141], neutrophils [142], and mast cells [143,144]. In this context, TAMs represent a central linker between chronic inflammation and cancer $[139,145]$. Regardless of their origin, these immune signals present in the TME play a crucial role in all stages of cancer evolution, from initiation to metastasis $[101,146,147]$. The release of pro-inflammatory mediators represents a central step in the cross talk between immune and cancer cells. It is driven by the activation of key transcription factors in response to different upstream stimuli (e.g., infection and pro-inflammatory cytokines) [145]. Among them, NF- $\mathrm{kB}$ and signal transducer and activator of transcription 3 (STAT3) have been shown to modulate the activation of numerous oncogenic pathways [148-153].

Notably, the regulation of these critical proteins and their relative pathways is extensively regulated at a post-transcriptional level by miRNAs (Figure 2). NF- $\mathrm{kB}$ is a major regulator of innate immunity and inflammation [150]. Downstream effects of NF-kB are cell-type dependent, consisting of induction of pro-inflammatory gene expression in immune cells, and of anti-apoptotic genes in tumor cells, favoring tumor development. A study published in 2009 by Bazzoni et al. [154] demonstrated the direct targeting of the NF- $\mathrm{KB} 1$ transcript by miR-9, with consequent reduction of pro-inflammatory cytokines. Due to the inflammatory microenvironment and oncogenic mutations, a significant number of human cancers have constitutive NF- $\mathrm{kB}$ activity that results in increased tumor proliferation and angiogenesis [155]. miR-9 deregulation in colon cancer cells has been consistently shown to suppress apoptosis and promote proliferation and tumor survival [156,157]. Other miRNAs have also been linked to the regulation of NF-KB signaling. In particular, miR-146a is involved in the control of inflammatory response. In particular, NF-kB-dependent miR-146a expression is induced in monocytes and macrophages upon triggering of TLR4 by LPS or other pro-inflammatory stimuli [128]. It downregulates the expression of the two adaptor proteins IRAK1 and TRAF6 (downstream of toll-like and cytokine receptors) and represses NF- $\mathrm{kB}$ signaling [128]. The miR-146a/NF- $\mathrm{kB}$ axis has been investigated in gastric and breast cancer cells, confirming the targeting of IRAK1 and TRAF6, and the consequent reduction of metastatic potential [133]. Two of the most important activators of NF-KB signaling are IL- 6 and TNF $\alpha$, which bind to their specific receptors (i.e., IL-6R and TNFR1/2, respectively) expressed by immune or cancer cells [158]. IL-6 and $\mathrm{TNF} \alpha$ are both pro-inflammatory cytokines, exerting pro-tumoral functions, including the promotion of angiogenesis and metastasis [159-162]. They are downregulated in human macrophages by several anti-inflammatory miRNAs, such as miR-187 [163], miR-146a [128], let-7e [164], and miR-92a [165] as a functional consequence of the direct targeting of molecular components participating in TLR signaling (Figure 2). STAT3 is constitutively activated in both tumor and immune cells by IL-6. 
STAT3 signaling is required for immunosuppressive and pro-tumorigenic function of both innate (MDSCs, TAMs) [166] and adaptive (Treg and Th17 lymphocytes) immune cells [167]. One of the first miRNAs described as an important regulator of STAT3 expression is miR-21. Expressed in both immune and cancer cells, miR-21 displays pro-inflammatory and pro-tumoral activity, respectively. miR-17-5p and miR-20a are two other important modulators of STAT3 expression, downregulated in MDSC s by tumor associated factors [168]. Ectopic expression of either miR-20a or miR-17-5p decreases MDSC s' ability to suppress antigen-specific CD4 and CD8 T cell responses [168]. Immunosuppressive and anti-inflammatory signals derive also from the actions of IL-10 and transforming growth factor $\beta$ (TGF- $\beta$ ), which have a general role in tumor suppression by inhibiting the production of pro-inflammatory cytokines [169-172]. They activate a negative feedback loop mechanism that induces the expression of other anti-inflammatory miRNA, such as miR-146b and miR-511-5p/3p [101,145,162]. These miRNAs have been recently described as part of the complex immune regulatory network of macrophage-derived anti-inflammatory response. Their specific role in in vivo tumor models has not been explored yet. Further investigations are needed to fully elucidate how miR-146b and miR-511 contribute to the antitumor immune response.

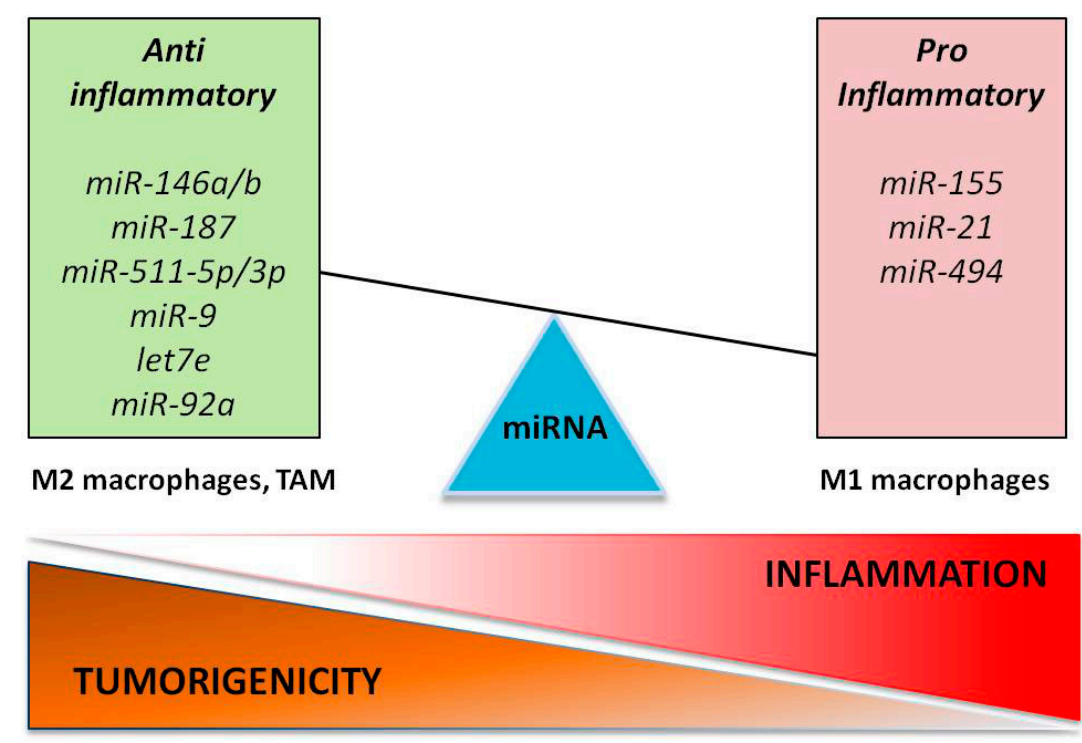

Figure 2. MiRNAs expression in macrophages modulates inflammation and carcinogenesis. MiRNAs modulate macrophage polarization from a pro-inflammatory M1 to an anti-inflammatory phenotype that inversely correlates with the tumorigenic potential of macrophages during carcinogenesis.

Altogether, this evidence strongly supports the notion that miRNAs participate in MDSCs and TAM-mediated modulation of the local inflammatory tumors. Our improved understanding of the connection between miRNAs, inflammation and cancer may provide novel preventive, diagnostic and therapeutic strategies.

\section{Exosome-Derived miRNAs in Cancer Progression and Metastasis}

Apart from their unique role as cytoplasmic regulators, recent evidence suggests that miRNAs are also components of a complex mechanism of indirect cell-to cell communication. They act as intercellular messengers transferred from donor to recipient cells through extracellular vesicles such as exosomes, altering gene expression in neighboring and even distant cells. Exosome-derived miRNAs are thought to play an important role in cell-to-cell communication, particularly in the cross talk between immune and tumor cells within the TME [173]. They are released from immune and non-immune cells, and are able to positively and negatively regulate the immune response (Table 2 and Figure 3). 
Table 2. Exosomal miRNAs functional activities in cancer. Exosomal miRNAs are secreted by macrophages and cancer cells and affect tumor initiation and progression by targeting key factors involved in survival, proliferation, invasion, and angiogenesis. Macrophage- and tumor-derived exosomal miRNAs recently described in the literature are reported here.

\begin{tabular}{|c|c|c|c|c|}
\hline miRNA & Donor Cells & Recipient Cells & Phenotype & \\
\hline $\operatorname{miR}-21$ & TAM & gastric cancer cells & $\uparrow$ cell proliferation $\downarrow$ chemosensitivity and apoptosis & \multirow{3}{*}{$\begin{array}{l}\text { TAM-derived exosomal } \\
\text { miRNAs }\end{array}$} \\
\hline miR-223 & TAM & breast cancer cells & $\uparrow$ cell migration capacity and invasiveness & \\
\hline miR-9 & TAM & endothelial cells & $\uparrow$ cell migration and angiogenesis & \\
\hline miR-940 & epithelial ovarian cancer & TAM & $\uparrow \mathrm{M} 2$ polarization & \multirow{13}{*}{$\begin{array}{l}\text { Tumor-secreted exosomal } \\
\text { miRNAs }\end{array}$} \\
\hline miR-203 & colorectal carcinoma & monocytes & $\uparrow \mathrm{M} 2$ polarization & \\
\hline miR-21 & solid tumor cells & macrophages & $\uparrow$ proliferation, survival, invasion and migration & \\
\hline miR-29b & solid tumor cells & macrophages & $\begin{array}{l}\text { OncomiR: } \uparrow \text { secretion of pro-metastatic and } \\
\text { pro-inflammatory cytokines }\end{array}$ & \\
\hline $\operatorname{miR}-9$ & tumor cell lines & cancer cells & OncomiR: $\uparrow$ endothelial cell migration $\uparrow$ tumor angiogenesis & \\
\hline miR-210 & breast cancer cells & adjacent cancer cells & OncomiR: $\uparrow$ angiogenesis & \\
\hline miR-105 & breast cancer cells & endothelial cells of distant organs & $\begin{array}{c}\text { OncomiR: } \uparrow \text { metastasis and vascular permeability by targeting the } \\
\text { tight junction protein } \mathrm{ZO}-1\end{array}$ & \\
\hline miR-200 & metastatic cancer cells & metastatic cancer cells & Regulates mesenchimal to epithelial transition & \\
\hline let-7e & gastric cancer cells & cancer cells & Tumor suppressor function (i.e., inhibits metastasis) & \\
\hline $\operatorname{miR}-23 b$ & bladder carcinoma cells & cancer cells & $\begin{array}{l}\text { Tumor suppressor function (e.g., inhibition angiogenesis, invasion } \\
\text { and metastasis) }\end{array}$ & \\
\hline miR-224 & bladder carcinoma cells & cancer cells & $\begin{array}{l}\text { Tumor suppressor functions (e.g., inhibition angiogenesis, invasion } \\
\text { and metastasis) }\end{array}$ & \\
\hline $\operatorname{miR}-921$ & bladder carcinoma cells & cancer cells & $\begin{array}{l}\text { Tumor suppressor functions (e.g., inhibition angiogenesis, invasion } \\
\text { and metastasis) }\end{array}$ & \\
\hline miR-15a & mesenchymal stromal cells & myeloma cells & Tumor suppressor function & \\
\hline
\end{tabular}




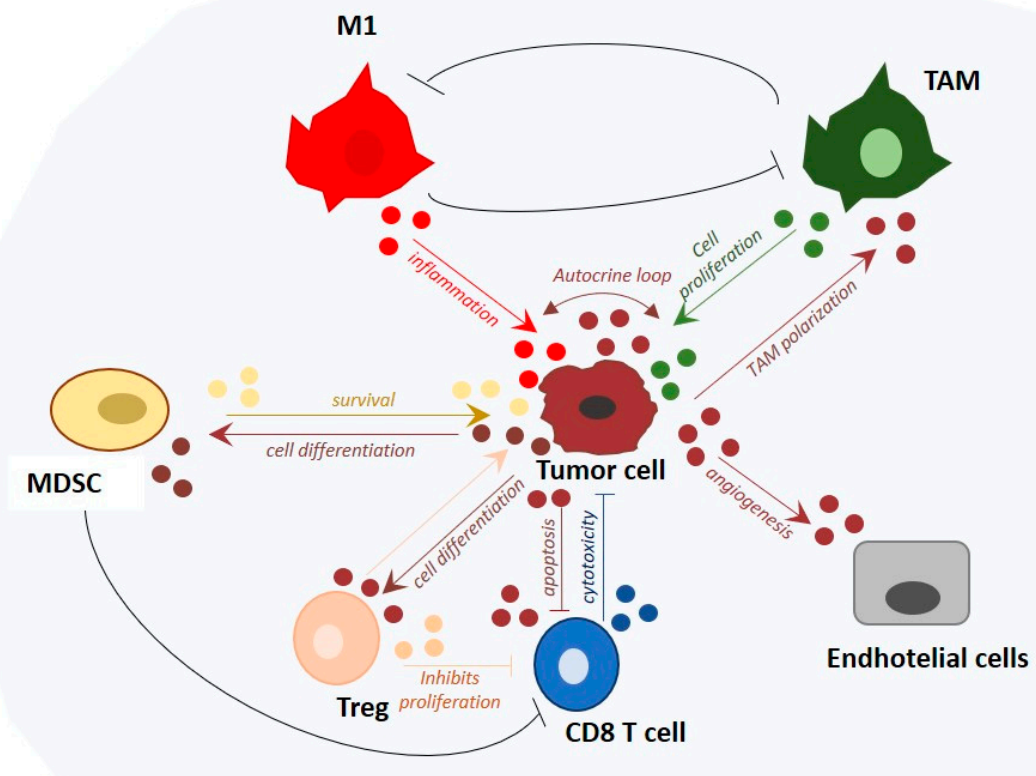

Tumor niche

Figure 3. Exosomal miRNAs as molecular messages exchanged between immune cells and tumor. The tumor microenvironment (TME) is a highly heterogeneous environment where different cell types, including macrophages, $\mathrm{T}$ lymphocytes, and endothelial cells, interact with each other by releasing exosomal miRNAs. The result of this interaction can lead to cell differentiation, survival, apoptosis, or angiogenesis, and strongly affects tumor initiation and progression.

With regards to the immune system, a pioneering study described in 2011 by Yang et al. [157], demonstrated that M2 macrophages were able to modulate invasiveness of breast cancer cells through exosome-mediated delivery of miR-223, which directly targets the Mef2c/ $\beta$-catenin pathway. The breast cancer cells acquired improved capacity for cell migration as a functional consequence of this horizontal genetic transfer. Since the publication of that study, many other miRNAs have been described as critical signaling molecule between tumor and host immune cells. In particular, exosomes-derived miR-940 released by hypoxic epithelial ovarian cancer induce TAM polarization [174]. High levels of miR-203 are present in the serum of colorectal carcinoma (CRC) patients and are associated with later metastasis and overall poor prognosis $[175,176]$. MiR-203 is shuttled to monocytes where it promotes the expression of M2 markers, thus favoring differentiation to TAM [159].

In the last few years new exosomal "oncomiRs" have been characterized, and it has become more and more evident that cancer-released exosomal miRNAs contribute to both progression of primary tumors and metastases. In particular, miR-21 is expressed and released by both TAMs and solid tumor-derived exosomes [160]. It is shuttled from TAM-derived exosomes to gastric cancer cells, where it suppresses apoptosis and enhances activation of PI3K/AKT signaling pathway by down-regulating PTEN. Moreover, miR-21 is also highly expressed in a wide range of solid tumors $[134,177]$ and secreted in plasma-derived exosomes from patients affected by different cancer types, including pancreatic, ovarian, lung, and colon carcinomas. Enforced expression of miR-21 promotes cellular proliferation, survival, invasion, and migration. Its expression positively correlates with tumor progression and invasiveness [134], while its knockdown decreases tumor cell survival and growth [178]. Interestingly, miR-21 has been described as a key player in a complex regulatory loop 
between cancer and immune cells, able to support the maintenance of a pro-tumorigenic inflammatory environment. Specifically, the secretion of the pro-inflammatory cytokine IL-6 from immune cells, promotes the invasiveness of tumor cells in an in vitro co-culture model of CRC [179,180]. As result, tumor cells secrete miR-21 and miR-29b into the TME, both of which have been shown to bind to TRLs in macrophages. This leads to the activation of NF- $\mathrm{KB}$ signaling pathway and the consequent secretion of pro-metastatic inflammatory cytokines [161]. Exosome-derived miRNAs also participate in cancer promotion by adapting the tumor niche cells. For instance, tumor-secreted miR-9 promotes endothelial cell migration and tumor angiogenesis [181], as does miR-210, an hypoxia-induced miRNA, with increased serum expression levels in breast cancer patients [182]. In this specific context, angiogenesis is enhanced as consequence of miR-210-mediated suppression of the receptor tyrosine kinase ligand ephrin-A3 (Efna3) and increased levels of VEGF [182]. Another example is miR-105, expressed and secreted by metastatic breast cancer cells [169]. miR-105 potently regulates cell migration; by targeting the tight junction protein $\mathrm{ZO}-1$, and thus impairing the integrity of natural cell barriers [169]. More recently, miR-200 family members have been described as able to be internalized by weakly metastatic cells to enhance tumor growth at metastatic lesions [183-185]. These findings suggest that horizontal transfer of exosomal miRNAs from cancer cells can facilitate remodeling of tissue architecture to promote cancer progression. Interestingly, several studies reported that cancer cells often secrete onco-suppressor miRNAs via exosomes [186]. Conversely, onco-suppressor miRNAs are less abundant in many solid tumor patients $[187,188]$ suggesting the hypothesis that, tumor suppressor miRNAs might be considered a form of anti-cancer defense mechanism in advanced cancer patients. An interesting example comes from a paper showing that let-7e family members are more highly expressed in exosomes derived from metastatic gastric cancer cells, relative to non-metastatic parental cells [189]. Many other miRNAs with tumor-suppressive functions have been described, including miR-224, miR-921, miR-23b, and miR-15a [190-192]. Another intriguing hypothesis supports the idea that in healthy individuals, a certain set of circulating miRNAs, with anti-tumor properties, might be part of a surveillance mechanism, complementary to the canonical cancer immune-surveillance system, exerting continuous inhibition on tumor formation and complementary to the canonical cancer immune-surveillance system $[139,193]$. This hypothetical action might add a further layer of host anti-tumor defense. However, the relevance of circulating miRNAs in healthy individuals is still unknown; the results presented so far are mainly based on expression profile studies; functional data in animal tumor models are still missing. Extensive studies to identify potential mRNA targets of miRNAs isolated from healthy donors and cancerous patients might provide insights on tumor suppressive or oncogenic mechanisms of circulating miRNAs.

\section{Immunogenic Cell Death: A Promising Tool for Anti-Cancer Immunotherapy}

We pointed out the existence of a dynamic cross-talk between tumors and immune cells that can either leads to progression or regression of the tumor, due to the simultaneous processing of both pro- and anti-growth signals. A major challenge for successful cancer treatment is the understanding of the molecular mechanisms to shift this balance, by favoring the selective killing of cancer cells. The old dogma according to which apoptotic cells do not trigger an immune response has been recently challenged by the emergence of the "immunogenic cell death" (ICD) concept. ICD refers to dying tumor cells, which release endogenous danger molecules, generally called damage-associated molecular patterns (DAMPs), after being exposed to chemotherapeutic agents (reviewed in [194,195]). DAMPs are then recognized by surface receptors expressed on innate immune cells, including pattern-recognition receptors (PRRs), phagocytosis-related receptors, and purinergic receptors, thereby eliciting an anti-tumor immune response. In physiological conditions, most of DAMPs such as calreticulin, adenosine triphosphate (ATP), heat shock protein 90 (HSP90) and high mobility group protein B1 (HMGB1), have predominantly non immunological functions. They are released in response to cellular stress conditions, including production reactive oxygen species (ROS) and endoplasmic reticulum (ER) stress. Interestingly, some of these DAMPs have been demonstrated to be targeted by miRNAs in 
physiological conditions and few reports also documented a correlation between expression levels of selective miRNAs and induction of tumor cell death by chemotoxic agents. In particular, miR-27a, an oncomiR upregulated in CRC, that directly targets calreticulin has been object of investigation in the study presented by Colangelo et al. in 2016 [196]. The authors demonstrated that upon chemoterapeutic exposure, CRC cells expressing low levels of miR-27 showed upregulated expression of calreticulin and HMGB1, increased release of ATP and enhanced apoptosis [196].

Despite these promising results, several questions remain to be addressed; in particular the molecular mechanisms involved and the impact of miRNA deregulation in the modulation of ICD. Further studies are also needed to define a potential therapeutic use of ICD determinants to trigger effective anti-tumor immune responses.

miRNAs as Therapeutic Agents in Cancer Treatment

In the last decade, advances in the field of cancer immunology have led to the emergence of immunotherapy as one of the most promising areas of cancer research and treatments [197-200]. Overall, the goal of cancer immunotherapy is to induce the patient's immune system to recognize cancer cells as foreign, and destroy them. Various immunotherapies either stimulate specific components of the immune system, or counteract tumor-derived signals that suppress immune responses. Recent advances have been made in the development of T cell-mediated immunotherapies. The most heralded of these are monoclonal antibodies directed at immune checkpoint modulators [199,201], and the clinical realization of chimeric antigen receptor (CAR) T cells [198] (Table 3). On the contrary, few therapies have been aimed at stimulating the response of myeloid cells against cancer [202,203]. In animal models, passive immunization with monoclonal antibodies against tumor antigens can stimulate macrophage-mediated phagocytosis of cancer cells and induce macrophage infiltration into the tumor milieu $[201,204]$.

Table 3. Immunological drugs in clinical development. List of immunological agents developed for treatment of malignancies. Drugs blocking immune checkpoints, CAR T cell therapies and miRNA-based drugs represent novel promising therapeutics in clinical development.

\begin{tabular}{|c|c|c|c|c|}
\hline & Immunological Target & Drug Name & Characteristics & Clinical Phase Testing \\
\hline \multirow{7}{*}{$\begin{array}{l}\text { Drugs blocking } \\
\text { Immune Checkpoints }\end{array}$} & \multirow{2}{*}{ anti-CTLA4 } & IPILIMUMAB & fully human IgG1 & approved, advanced melanoma \\
\hline & & TREMELIMUMAB & fully human IgG2 & failed phase III trial melanoma \\
\hline & \multirow[t]{2}{*}{ anti-PD1 } & PEMBROLIZUMAB & fully human IgG4 & approved, melanoma \\
\hline & & PIDILIZUMAB & humanized IgG1 & phase I-II trial \\
\hline & \multirow{3}{*}{ anti-PD-L1 } & MSB0010718C & fully human IgG1 & phase I-II trial \\
\hline & & MEDI4736 & Fc-modified human IgG1 & phase I-III trial \\
\hline & & MPDL3280A & Fc-modified human IgG1 & phase I-III trial \\
\hline \multirow{3}{*}{ CAR T cells therapy } & anti-CD19 & $\begin{array}{l}\text { TISAGENLECLEUCEL-T } \\
\left(\text { Kimryah }^{\mathrm{TM}}\right)\end{array}$ & chimeric antigen receptor $\mathrm{T}$ cells & approved, Acute lymphatic leukemia \\
\hline & anti-CD30 & NCT02259556 & chimeric antigen receptor $\mathrm{T}$ cells & phase II-III trial, Hodgkin lymphoma \\
\hline & anti-EGFR & NCT01869166 & chimeric antigen receptor $\mathrm{T}$ cells & $\begin{array}{l}\text { phase II-III trial, Advanced } \\
\text { lung cancer }\end{array}$ \\
\hline \multirow{5}{*}{ miRNA-based drugs } & miR-34 & MRX34 & miRNA mimic & $\begin{array}{c}\text { phase I trial, advanced } \\
\text { hepatocarcinoma }\end{array}$ \\
\hline & miR-122 & MIRAVIRSEN & LNA-based antimiRNA & phase II trial, HCV \\
\hline & miR-29b & MRG-201 & miRNA mimic & phase I trial, fibrotic diseases \\
\hline & miR-155 & MRG-106 & AntimiRNA & $\begin{array}{c}\text { phase I trial, } \\
\text { hematological malignances }\end{array}$ \\
\hline & $\mathrm{miR}-10 \mathrm{~b}$ & - & AntimiRNA & preclinical phase, glioblastoma \\
\hline
\end{tabular}


Compared to other drugs currently on the market for cancer treatment, the intrinsic ability of miRNAs to simultaneously affect gene expression of multiple different pathways makes them an attractive tool for the development of effective drugs. As discussed in the previous sections, miRNAs dysregulation plays a critical role in cancer development, as they are entangled with many of the hallmarks of cancer $[205,206]$. Therefore, an effective therapeutic strategy might consist in the modulation of specific miRNAs. This can be achieved by specific targeting of cancer-relevant miRNAs at different levels of their biogenesis and activity. Promising results have been obtained in preclinical studies with the use of miRNA antagonists, called antagomiRs, and miRNA mimics to reduce or enhance miRNA activity, respectively (Table 3). AntagomiRs are chemically modified single stranded DNA oligonucleotides complementary to the miRNA sequence, that function as miRNA antagonists and can be employed to repress the activity of oncomiRs, by competing with native tumor-suppressing target transcripts [173]. miRNA mimics are chemically-modified short double-stranded oligonucleotides, that functionally mimic pre-miRNA duplexes; hence they are processed by native cellular pathways to increase expression levels of tumor suppressor miRNAs [155]. To increase their stability and ensure specificity chemical modification have been introduced, including: methoxyethyll-4'-thioRNA (MOE-SRNA), cholesterol-conjugated 2'-O methylated miRNA mimic/antagomiRs, and locked nucleic acid (LNA)- modified anti-miRNAs [150].

However, a remaining challenge is the successful delivery of these therapeutic molecules to specific tissue and cells. Indeed, given the pleiotropic role of miRNAs and their ability to function in a cell type-dependent manner, the design of an effective delivery system is critical to guarantee tissue and cell specificity in order to reduce the risk of toxicity and side effects. Different types of biodegradable and biocompatible miRNA carriers have been synthesized as biodegradable and biocompatible, including liposomes, nanoparticles, polymers and viral agents. The versatility of liposomal carriers made them suitable vehicles for co-delivery of miRNAs and small-molecule drugs, which concurrently are able to target the same cancer cell, in an effective synergistic antitumor way. Liposomal carriers were firstly employed for siRNA and small conventional drugs delivery in clinical trials. A liposomal formulation of a mimic of the tumor-suppressive miR-34 was first characterized in animal model of liver cancer [150] and recently reached clinical development. Recently, another miR-34 mimic entered phase I clinical trials for the treatment of advanced hepatocarcinoma [149] (Table 3). Studies have also investigated the use in clinics of viral-based delivery systems [152]. In particular, lentiviral vectors containing antagomiRs against miR-494 have been shown to reduce tumor-infiltrating MDSCs and their protumor activity in an in vivo model of breast cancer [82]. However, the potential risk of therapeutic lentiviral vectors is due to their intrinsic nature to integrate themselves into the human genome. To bypass this risk, adenoviruses and adeno-associated viruses might be more suitable for therapeutic purposes, due to their non-integrative activity. However, limits in large-scale production as well as the immunogenic potential still remain major issues in their effective and safe use in therapy. Therefore, non-viral delivery strategies have received more interest. In particular, cell-derived exosomes containing immune-related miRNAs have the potential to be employed as therapeutic agents. Accordingly, exosome- and immune cell-based delivery represent two interesting potential strategies for miRNA-based cancer immunotherapy. The use of tumor-derived extracellular vesicles to deliver therapeutic miRNAs was recently reported, wherein the authors described the efficient delivery of the tumor suppressive miRNA let-7a to epidermal growth factor receptor (EGFR)-expressing breast cancer cells in vivo. However, the use of exosomes as miRNAs vehicles in cancer therapies is only at the beginning and needs to be further investigated. Possible strategies to improve target selectivity are the modification of the vesicular membrane with ligands or antibodies targeted to the endogenous receptors of tumor or stromal cells. In this context, the combination of miRNA-related immunotherapy with conventional cytotoxic drug agents or targeted therapy would represent a valuable opportunity for effective therapeutic interventions in human malignancies. 


\section{Conclusions}

The prominent role of miRNAs as molecular determinants of the innate immune response qualifies them as novel potential therapeutic agents that could critically modulate the fine balance of innate immune cells involved in cancer progression.

Acknowledgments: The author thanks K.C. Pels for his help in editing and proofreading the paper.

Conflicts of Interest: The author declares no conflict of interest.

\section{References}

1. Bui, J.D.; Schreiber, R.D. Cancer immunosurveillance, immunoediting and inflammation: Independent or interdependent processes? Curr. Opin. Immunol. 2007, 19, 203-208. [CrossRef] [PubMed]

2. Hagerling, C.; Casbon, A.J.; Werb, Z. Balancing the innate immune system in tumor development. Trends Cell Biol. 2015, 25, 214-220. [CrossRef] [PubMed]

3. Wang, M.; Zhao, J.; Zhang, L.; Wei, F.; Lian, Y.; Wu, Y.; Gong, Z.; Zhang, S.; Zhou, J.; Cao, K.; et al. Role of tumor microenvironment in tumorigenesis. J. Cancer 2017, 8, 761-773. [CrossRef] [PubMed]

4. Joyce, J.A.; Fearon, D.T. T cell exclusion, immune privilege, and the tumor microenvironment. Science 2015, 348, 74-80. [CrossRef] [PubMed]

5. Burnet, F.M. The concept of immunological surveillance. Prog. Exp. Tumor Res. 1970, 13, 1-27. [PubMed]

6. Burnet, M. Cancer, a biological approach. I. The processes of control. Br. Med. J. 1957, 1, 779-786. [CrossRef] [PubMed]

7. Burnet, M. Immunological Factors in the Process of Carcinogenesis. Br. Med. Bull. 1964, 20, 154-158. [CrossRef] [PubMed]

8. DuPage, M.; Mazumdar, C.; Schmidt, L.M.; Cheung, A.F.; Jacks, T. Expression of tumour-specific antigens underlies cancer immunoediting. Nature 2012, 482, 405-409. [CrossRef] [PubMed]

9. Street, S.E.; Cretney, E.; Smyth, M.J. Perforin and interferon-gamma activities independently control tumor initiation, growth, and metastasis. Blood 2001, 97, 192-197. [CrossRef] [PubMed]

10. Street, S.E.; Trapani, J.A.; MacGregor, D.; Smyth, M.J. Suppression of lymphoma and epithelial malignancies effected by interferon gamma. J. Exp. Med. 2002, 196, 129-134. [CrossRef] [PubMed]

11. Shinkai, Y.; Rathbun, G.; Lam, K.P.; Oltz, E.M.; Stewart, V.; Mendelsohn, M.; Charron, J.; Datta, M.; Young, F.; Stall, A.M.; et al. RAG-2-deficient mice lack mature lymphocytes owing to inability to initiate V(D)J rearrangement. Cell 1992, 68, 855-867. [CrossRef]

12. Shankaran, V.; Ikeda, H.; Bruce, A.T.; White, J.M.; Swanson, P.E.; Old, L.J.; Schreiber, R.D. IFNgamma and lymphocytes prevent primary tumour development and shape tumour immunogenicity. Nature 2001, 410, 1107-1111. [CrossRef] [PubMed]

13. Smyth, M.J.; Thia, K.Y.; Street, S.E.; MacGregor, D.; Godfrey, D.I.; Trapani, J.A. Perforin-mediated cytotoxicity is critical for surveillance of spontaneous lymphoma. J. Exp. Med. 2000, 192, 755-760. [CrossRef] [PubMed]

14. Mittal, D.; Gubin, M.M.; Schreiber, R.D.; Smyth, M.J. New insights into cancer immunoediting and its three component phases-Elimination, equilibrium and escape. Curr. Opin. Immunol. 2014, 27, 16-25. [CrossRef] [PubMed]

15. Lagos-Quintana, M.; Rauhut, R.; Lendeckel, W.; Tuschl, T. Identification of novel genes coding for small expressed RNAs. Science 2001, 294, 853-858. [CrossRef] [PubMed]

16. Lujambio, A.; Calin, G.A.; Villanueva, A.; Ropero, S.; Sanchez-Cespedes, M.; Blanco, D.; Montuenga, L.M.; Rossi, S.; Nicoloso, M.S.; Faller, W.J.; et al. A microRNA DNA methylation signature for human cancer metastasis. Proc. Natl. Acad. Sci. USA 2008, 105, 13556-13561. [CrossRef] [PubMed]

17. Hammond, S.M.; Caudy, A.A.; Hannon, G.J. Post-transcriptional gene silencing by double-stranded RNA. Nat. Rev. Genet. 2001, 2, 110-119. [CrossRef] [PubMed]

18. Ambros, V. microRNAs: Tiny regulators with great potential. Cell 2001, 107, 823-826. [CrossRef]

19. Kirigin, F.F.; Lindstedt, K.; Sellars, M.; Ciofani, M.; Low, S.L.; Jones, L.; Bell, F.; Pauli, F.; Bonneau, R.; Myers, R.M.; et al. Dynamic microRNA gene transcription and processing during $\mathrm{T}$ cell development. J. Immunol. 2012, 188, 3257-3267. [CrossRef] [PubMed] 
20. Lee, Y.; Kim, M.; Han, J.; Yeom, K.H.; Lee, S.; Baek, S.H.; Kim, V.N. MicroRNA genes are transcribed by RNA polymerase II. EMBO J. 2004, 23, 4051-4060. [CrossRef] [PubMed]

21. Kim, Y.K.; Kim, B.; Kim, V.N. Re-evaluation of the roles of DROSHA, Export in 5, and DICER in microRNA biogenesis. Proc. Natl. Acad. Sci. USA 2016, 113, E1881-E1889. [CrossRef] [PubMed]

22. Gregory, R.I.; Yan, K.P.; Amuthan, G.; Chendrimada, T.; Doratotaj, B.; Cooch, N.; Shiekhattar, R. The Microprocessor complex mediates the genesis of microRNAs. Nature 2004, 432, 235-240. [CrossRef] [PubMed]

23. Triboulet, R.; Chang, H.M.; Lapierre, R.J.; Gregory, R.I. Post-transcriptional control of DGCR8 expression by the Microprocessor. RNA 2009, 15, 1005-1011. [CrossRef] [PubMed]

24. Bohnsack, M.T.; Czaplinski, K.; Gorlich, D. Exportin 5 is a RanGTP-dependent dsRNA-binding protein that mediates nuclear export of pre-miRNAs. RNA 2004, 10, 185-191. [CrossRef] [PubMed]

25. Lund, E.; Dahlberg, J.E. Substrate selectivity of exportin 5 and Dicer in the biogenesis of microRNAs. Cold Spring Harb. Symp. Quant. Biol. 2006, 71, 59-66. [CrossRef] [PubMed]

26. Grishok, A.; Pasquinelli, A.E.; Conte, D.; Li, N.; Parrish, S.; Ha, I.; Baillie, D.L.; Fire, A.; Ruvkun, G.; Mello, C.C. Genes and mechanisms related to RNA interference regulate expression of the small temporal RNAs that control C. elegans developmental timing. Cell 2001, 106, 23-34. [CrossRef]

27. Hammond, S.M.; Bernstein, E.; Beach, D.; Hannon, G.J. An RNA-directed nuclease mediates post-transcriptional gene silencing in Drosophila cells. Nature 2000, 404, 293-296. [CrossRef] [PubMed]

28. Gregory, R.I.; Chendrimada, T.P.; Cooch, N.; Shiekhattar, R. Human RISC couples microRNA biogenesis and posttranscriptional gene silencing. Cell 2005, 123, 631-640. [CrossRef] [PubMed]

29. Hammond, S.M.; Boettcher, S.; Caudy, A.A.; Kobayashi, R.; Hannon, G.J. Argonaute2, a link between genetic and biochemical analyses of RNAi. Science 2001, 293, 1146-1150. [CrossRef] [PubMed]

30. De Moor, C.H.; Meijer, H.; Lissenden, S. Mechanisms of translational control by the 3' UTR in development and differentiation. Semin. Cell Dev. Biol. 2005, 16, 49-58. [CrossRef] [PubMed]

31. Watanabe, K.; Emoto, N.; Hamano, E.; Sunohara, M.; Kawakami, M.; Kage, H.; Kitano, K.; Nakajima, J.; Goto, A.; Fukayama, M.; et al. Genome structure-based screening identified epigenetically silenced microRNA associated with invasiveness in non-small-cell lung cancer. Int. J. Cancer 2012, 130, 2580-2590. [CrossRef] [PubMed]

32. Lai, E.C. Micro RNAs are complementary to $3^{\prime}$ UTR sequence motifs that mediate negative post-transcriptional regulation. Nat. Genet. 2002, 30, 363-364. [CrossRef] [PubMed]

33. Ozsolak, F.; Poling, L.L.; Wang, Z.; Liu, H.; Liu, X.S.; Roeder, R.G.; Zhang, X.; Song, J.S.; Fisher, D.E. Chromatin structure analyses identify miRNA promoters. Genes Dev. 2008, 22, 3172-3183. [CrossRef] [PubMed]

34. Fabian, M.R.; Sonenberg, N.; Filipowicz, W. Regulation of mRNA translation and stability by microRNAs. Annu. Rev. Biochem. 2010, 79, 351-379. [CrossRef] [PubMed]

35. Berezikov, E.; Guryev, V.; van de Belt, J.; Wienholds, E.; Plasterk, R.H.; Cuppen, E. Phylogenetic shadowing and computational identification of human microRNA genes. Cell 2005, 120, 21-24. [CrossRef] [PubMed]

36. Boffelli, D.; McAuliffe, J.; Ovcharenko, D.; Lewis, K.D.; Ovcharenko, I.; Pachter, L.; Rubin, E.M. Phylogenetic shadowing of primate sequences to find functional regions of the human genome. Science 2003, 299, 1391-1394. [CrossRef] [PubMed]

37. Lewis, B.P.; Burge, C.B.; Bartel, D.P. Conserved seed pairing, often flanked by adenosines, indicates that thousands of human genes are microRNA targets. Cell 2005, 120, 15-20. [CrossRef] [PubMed]

38. John, B.; Enright, A.J.; Aravin, A.; Tuschl, T.; Sander, C.; Marks, D.S. Human MicroRNA targets. PLoS Biol. 2004, 2, e363. [CrossRef] [PubMed]

39. Shivdasani, R.A. MicroRNAs: Regulators of gene expression and cell differentiation. Blood 2006, 108, $3646-3653$. [CrossRef] [PubMed]

40. He, L.; Hannon, G.J. MicroRNAs: Small RNAs with a big role in gene regulation. Nat. Rev. Genet. 2004, 5, $522-531$. [CrossRef] [PubMed]

41. Cheng, A.M.; Byrom, M.W.; Shelton, J.; Ford, L.P. Antisense inhibition of human miRNAs and indications for an involvement of miRNA in cell growth and apoptosis. Nucleic Acids Res. 2005, 33, 1290-1297. [CrossRef] [PubMed]

42. Cimmino, A.; Calin, G.A.; Fabbri, M.; Iorio, M.V.; Ferracin, M.; Shimizu, M.; Wojcik, S.E.; Aqeilan, R.I.; Zupo, S.; Dono, M.; et al. miR-15 and miR-16 induce apoptosis by targeting BCL2. Proc. Natl. Acad. Sci. USA 2005, 102, 13944-13949. [CrossRef] [PubMed] 
43. Suzuki, H.; Yamamoto, E.; Nojima, M.; Kai, M.; Yamano, H.O.; Yoshikawa, K.; Kimura, T.; Kudo, T.; Harada, E.; Sugai, T.; et al. Methylation-associated silencing of microRNA-34b/c in gastric cancer and its involvement in an epigenetic field defect. Carcinogenesis 2010, 31, 2066-2073. [CrossRef] [PubMed]

44. Agirre, X.; Vilas-Zornoza, A.; Jimenez-Velasco, A.; Martin-Subero, J.I.; Cordeu, L.; Garate, L.; San Jose-Eneriz, E.; Abizanda, G.; Rodriguez-Otero, P.; Fortes, P.; et al. Epigenetic silencing of the tumor suppressor microRNA Hsa-miR-124a regulates CDK6 expression and confers a poor prognosis in acute lymphoblastic leukemia. Cancer Res. 2009, 69, 4443-4453. [CrossRef] [PubMed]

45. Calin, G.A.; Dumitru, C.D.; Shimizu, M.; Bichi, R.; Zupo, S.; Noch, E.; Aldler, H.; Rattan, S.; Keating, M.; Rai, K.; et al. Frequent deletions and down-regulation of micro-RNA genes miR15 and miR16 at 13q14 in chronic lymphocytic leukemia. Proc. Natl. Acad. Sci. USA 2002, 99, 15524-15529. [CrossRef] [PubMed]

46. Volinia, S.; Calin, G.A.; Liu, C.G.; Ambs, S.; Cimmino, A.; Petrocca, F.; Visone, R.; Iorio, M.; Roldo, C.; Ferracin, M.; et al. A microRNA expression signature of human solid tumors defines cancer gene targets. Proc. Natl. Acad. Sci. USA 2006, 103, 2257-2261. [CrossRef] [PubMed]

47. Wang, P.; Chen, L.; Zhang, J.; Chen, H.; Fan, J.; Wang, K.; Luo, J.; Chen, Z.; Meng, Z.; Liu, L. Methylation-mediated silencing of the miR-124 genes facilitates pancreatic cancer progression and metastasis by targeting Rac1. Oncogene 2014, 33, 514-524. [CrossRef] [PubMed]

48. Wong, K.Y.; So, C.C.; Loong, F.; Chung, L.P.; Lam, W.W.; Liang, R.; Li, G.K.; Jin, D.Y.; Chim, C.S. Epigenetic inactivation of the miR-124-1 in haematological malignancies. PLoS ONE 2011, 6, e19027. [CrossRef] [PubMed]

49. Kumar, M.S.; Lu, J.; Mercer, K.L.; Golub, T.R.; Jacks, T. Impaired microRNA processing enhances cellular transformation and tumorigenesis. Nat. Genet. 2007, 39, 673-677. [CrossRef] [PubMed]

50. Calin, G.A.; Sevignani, C.; Dumitru, C.D.; Hyslop, T.; Noch, E.; Yendamuri, S.; Shimizu, M.; Rattan, S.; Bullrich, F.; Negrini, M.; et al. Human microRNA genes are frequently located at fragile sites and genomic regions involved in cancers. Proc. Natl. Acad. Sci. USA 2004, 101, 2999-3004. [CrossRef] [PubMed]

51. Sevignani, C.; Calin, G.A.; Nnadi, S.C.; Shimizu, M.; Davuluri, R.V.; Hyslop, T.; Demant, P.; Croce, C.M.; Siracusa, L.D. MicroRNA genes are frequently located near mouse cancer susceptibility loci. Proc. Natl. Acad. Sci. USA 2007, 104, 8017-8022. [CrossRef] [PubMed]

52. Creighton, C.J.; Hernandez-Herrera, A.; Jacobsen, A.; Levine, D.A.; Mankoo, P.; Schultz, N.; Du, Y.; Zhang, Y.; Larsson, E.; Sheridan, R.; et al. Integrated analyses of microRNAs demonstrate their widespread influence on gene expression in high-grade serous ovarian carcinoma. PLoS ONE 2012, 7, e34546. [CrossRef] [PubMed]

53. Bayani, J.; Kuzmanov, U.; Saraon, P.; Fung, W.A.; Soosaipillai, A.; Squire, J.A.; Diamandis, E.P. Copy number and expression alterations of miRNAs in the ovarian cancer cell line OVCAR-3: Impact on kallikrein 6 protein expression. Clin. Chem. 2013, 59, 296-305. [CrossRef] [PubMed]

54. Imam, J.S.; Plyler, J.R.; Bansal, H.; Prajapati, S.; Bansal, S.; Rebeles, J.; Chen, H.I.; Chang, Y.F.; Panneerdoss, S.; Zoghi, B.; et al. Genomic loss of tumor suppressor miRNA-204 promotes cancer cell migration and invasion by activating AKT/mTOR/Rac1 signaling and actin reorganization. PLoS ONE 2012, 7, e52397. [CrossRef] [PubMed]

55. Weber, B.; Stresemann, C.; Brueckner, B.; Lyko, F. Methylation of human microRNA genes in normal and neoplastic cells. Cell Cycle 2007, 6, 1001-1005. [CrossRef] [PubMed]

56. Saito, Y.; Liang, G.; Egger, G.; Friedman, J.M.; Chuang, J.C.; Coetzee, G.A.; Jones, P.A. Specific activation of microRNA-127 with downregulation of the proto-oncogene BCL6 by chromatin-modifying drugs in human cancer cells. Cancer Cell 2006, 9, 435-443. [CrossRef] [PubMed]

57. Lehmann, U.; Hasemeier, B.; Christgen, M.; Muller, M.; Romermann, D.; Langer, F.; Kreipe, H. Epigenetic inactivation of microRNA gene hsa-mir-9-1 in human breast cancer. J. Pathol. 2008, 214, 17-24. [CrossRef] [PubMed]

58. Scott, G.K.; Mattie, M.D.; Berger, C.E.; Benz, S.C.; Benz, C.C. Rapid alteration of microRNA levels by histone deacetylase inhibition. Cancer Res. 2006, 66, 1277-1281. [CrossRef] [PubMed]

59. Wee, E.J.; Peters, K.; Nair, S.S.; Hulf, T.; Stein, S.; Wagner, S.; Bailey, P.; Lee, S.Y.; Qu, W.J.; Brewster, B.; et al. Mapping the regulatory sequences controlling 93 breast cancer-associated miRNA genes leads to the identification of two functional promoters of the Hsa-mir-200b cluster, methylation of which is associated with metastasis or hormone receptor status in advanced breast cancer. Oncogene 2012, 31, 4182-4195. [CrossRef] [PubMed] 
60. Bandres, E.; Agirre, X.; Bitarte, N.; Ramirez, N.; Zarate, R.; Roman-Gomez, J.; Prosper, F.; Garcia-Foncillas, J. Epigenetic regulation of microRNA expression in colorectal cancer. Int. J. Cancer 2009, 125, 2737-2743. [CrossRef] [PubMed]

61. Roman-Gomez, J.; Agirre, X.; Jimenez-Velasco, A.; Arqueros, V.; Vilas-Zornoza, A.; Rodriguez-Otero, P.; Martin-Subero, I.; Garate, L.; Cordeu, L.; San Jose-Eneriz, E.; et al. Epigenetic regulation of microRNAs in acute lymphoblastic leukemia. J. Clin. Oncol. 2009, 27, 1316-1322. [CrossRef] [PubMed]

62. Gebauer, K.; Peters, I.; Dubrowinskaja, N.; Hennenlotter, J.; Abbas, M.; Scherer, R.; Tezval, H.; Merseburger, A.S.; Stenzl, A.; Kuczyk, M.A.; et al. Hsa-mir-124-3 CpG island methylation is associated with advanced tumours and disease recurrence of patients with clear cell renal cell carcinoma. Br. J. Cancer 2013, 108, 131-138. [CrossRef] [PubMed]

63. Furuta, M.; Kozaki, K.I.; Tanaka, S.; Arii, S.; Imoto, I.; Inazawa, J. miR-124 and miR-203 are epigenetically silenced tumor-suppressive microRNAs in hepatocellular carcinoma. Carcinogenesis 2010, 31, 766-776. [CrossRef] [PubMed]

64. Melo, S.A.; Moutinho, C.; Ropero, S.; Calin, G.A.; Rossi, S.; Spizzo, R.; Fernandez, A.F.; Davalos, V.; Villanueva, A.; Montoya, G.; et al. A genetic defect in exportin-5 traps precursor microRNAs in the nucleus of cancer cells. Cancer Cell 2010, 18, 303-315. [CrossRef] [PubMed]

65. Melo, S.A.; Ropero, S.; Moutinho, C.; Aaltonen, L.A.; Yamamoto, H.; Calin, G.A.; Rossi, S.; Fernandez, A.F.; Carneiro, F.; Oliveira, C.; et al. A TARBP2 mutation in human cancer impairs microRNA processing and DICER1 function. Nat. Genet. 2009, 41, 365-370. [CrossRef] [PubMed]

66. Kumar, M.S.; Pester, R.E.; Chen, C.Y.; Lane, K.; Chin, C.; Lu, J.; Kirsch, D.G.; Golub, T.R.; Jacks, T. Dicer1 functions as a haploinsufficient tumor suppressor. Genes Dev. 2009, 23, 2700-2704. [CrossRef] [PubMed]

67. Suzuki, H.I.; Yamagata, K.; Sugimoto, K.; Iwamoto, T.; Kato, S.; Miyazono, K. Modulation of microRNA processing by p53. Nature 2009, 460, 529-533. [CrossRef] [PubMed]

68. Garibaldi, F.; Falcone, E.; Trisciuoglio, D.; Colombo, T.; Lisek, K.; Walerych, D.; Del Sal, G.; Paci, P.; Bossi, G.; Piaggio, G.; et al. Mutant p53 inhibits miRNA biogenesis by interfering with the microprocessor complex. Oncogene 2016, 35, 3760-3770. [CrossRef] [PubMed]

69. Mayr, C.; Bartel, D.P. Widespread shortening of $3^{\prime} U T R s$ by alternative cleavage and polyadenylation activates oncogenes in cancer cells. Cell 2009, 138, 673-684. [CrossRef] [PubMed]

70. Mayr, C.; Hemann, M.T.; Bartel, D.P. Disrupting the pairing between let-7 and Hmga2 enhances oncogenic transformation. Science 2007, 315, 1576-1579. [CrossRef] [PubMed]

71. Lee, Y.S.; Dutta, A. The tumor suppressor microRNA let-7 represses the HMGA2 oncogene. Genes Dev. 2007, 21, 1025-1030. [CrossRef] [PubMed]

72. Chin, L.J.; Ratner, E.; Leng, S.; Zhai, R.; Nallur, S.; Babar, I.; Muller, R.U.; Straka, E.; Su, L.; Burki, E.A.; et al. A SNP in a let-7 microRNA complementary site in the KRAS $3^{\prime}$ untranslated region increases non-small cell lung cancer risk. Cancer Res. 2008, 68, 8535-8540. [CrossRef] [PubMed]

73. Martinez, F.O.; Gordon, S. The M1 and M2 paradigm of macrophage activation: Time for reassessment. F1000prime Rep. 2014, 6, 13. [CrossRef] [PubMed]

74. Zhang, Y.; Zhang, M.; Zhong, M.; Suo, Q.; Lv, K. Expression profiles of miRNAs in polarized macrophages. Int. J. Mol. Med. 2013, 31, 797-802. [CrossRef] [PubMed]

75. Liu, G.; Abraham, E. MicroRNAs in immune response and macrophage polarization. Arterioscler. Thromb. Vasc. Biol. 2013, 33, 170-177. [CrossRef] [PubMed]

76. Cobos Jimenez, V.; Bradley, E.J.; Willemsen, A.M.; van Kampen, A.H.; Baas, F.; Kootstra, N.A. Next-generation sequencing of microRNAs uncovers expression signatures in polarized macrophages. Physiol. Genom. 2014, 46, 91-103. [CrossRef] [PubMed]

77. O'Connell, R.M.; Chaudhuri, A.A.; Rao, D.S.; Baltimore, D. Inositol phosphatase SHIP1 is a primary target of miR-155. Proc. Natl. Acad. Sci. USA 2009, 106, 7113-7118. [CrossRef] [PubMed]

78. O'Connell, R.M.; Taganov, K.D.; Boldin, M.P.; Cheng, G.; Baltimore, D. MicroRNA-155 is induced during the macrophage inflammatory response. Proc. Natl. Acad. Sci. USA 2007, 104, 1604-1609. [CrossRef] [PubMed]

79. Cui, B.; Chen, L.; Zhang, S.; Mraz, M.; Fecteau, J.F.; Yu, J.; Ghia, E.M.; Zhang, L.; Bao, L.; Rassenti, L.Z.; et al. MicroRNA-155 influences B-cell receptor signaling and associates with aggressive disease in chronic lymphocytic leukemia. Blood 2014, 124, 546-554. [CrossRef] [PubMed] 
80. Singh, U.P.; Murphy, A.E.; Enos, R.T.; Shamran, H.A.; Singh, N.P.; Guan, H.; Hegde, V.L.; Fan, D.; Price, R.L.; Taub, D.D.; et al. miR-155 deficiency protects mice from experimental colitis by reducing $\mathrm{T}$ helper type 1/type 17 responses. Immunology 2014, 143, 478-489. [CrossRef] [PubMed]

81. Martinez-Nunez, R.T.; Louafi, F.; Sanchez-Elsner, T. The interleukin 13 (IL-13) pathway in human macrophages is modulated by microRNA-155 via direct targeting of interleukin 13 receptor alpha1 (IL13Ralpha1). J. Biol. Chem. 2011, 286, 1786-1794. [CrossRef] [PubMed]

82. Chaudhuri, A.A.; So, A.Y.; Sinha, N.; Gibson, W.S.; Taganov, K.D.; O'Connell, R.M.; Baltimore, D. MicroRNA-125b potentiates macrophage activation. J. Immunol. 2011, 187, 5062-5068. [CrossRef] [PubMed]

83. Ying, H.; Kang, Y.; Zhang, H.; Zhao, D.; Xia, J.; Lu, Z.; Wang, H.; Xu, F.; Shi, L. MiR-127 modulates macrophage polarization and promotes lung inflammation and injury by activating the JNK pathway. J. Immunol. 2015, 194, 1239-1251. [CrossRef] [PubMed]

84. Li, D.; Duan, M.; Feng, Y.; Geng, L.; Li, X.; Zhang, W. MiR-146a modulates macrophage polarization in systemic juvenile idiopathic arthritis by targeting INHBA. Mol. Immunol. 2016, 77, 205-212. [CrossRef] [PubMed]

85. Huang, C.; Liu, X.J.; Xie, J.; Ma, T.T.; Meng, X.M.; Li, J. MiR-146a modulates macrophage polarization by inhibiting Notch1 pathway in RAW264.7 macrophages. Int. Immunopharmacol. 2016, 32, 46-54. [CrossRef] [PubMed]

86. Haneklaus, M.; Gerlic, M.; O’Neill, L.A.; Masters, S.L. miR-223: Infection, inflammation and cancer. J. Int. Med. 2013, 274, 215-226. [CrossRef] [PubMed]

87. Banerjee, S.; Xie, N.; Cui, H.; Tan, Z.; Yang, S.; Icyuz, M.; Abraham, E.; Liu, G. MicroRNA let-7c regulates macrophage polarization. J. Immunol. 2013, 190, 6542-6549. [CrossRef] [PubMed]

88. Zhang, W.; Liu, H.; Liu, W.; Liu, Y.; Xu, J. Polycomb-mediated loss of microRNA let-7c determines inflammatory macrophage polarization via PAK1-dependent NF-kappaB pathway. Cell Death Differ. 2015, 22, 287-297. [CrossRef] [PubMed]

89. Qin, H.; Holdbrooks, A.T.; Liu, Y.; Reynolds, S.L.; Yanagisawa, L.L.; Benveniste, E.N. Correction: SOCS3 Deficiency Promotes M1 Macrophage Polarization and Inflammation. J. Immunol. 2016, 197, 387-389. [CrossRef] [PubMed]

90. Zhang, A.; Qian, Y.; Ye, Z.; Chen, H.; Xie, H.; Zhou, L.; Shen, Y.; Zheng, S. Cancer-associated fibroblasts promote M2 polarization of macrophages in pancreatic ductal adenocarcinoma. Cancer Med. 2017, 6, 463-470. [CrossRef] [PubMed]

91. Deng, X.; Zhang, P.; Liang, T.; Deng, S.; Chen, X.; Zhu, L. Ovarian cancer stem cells induce the M2 polarization of macrophages through the PPARgamma and NF-kappaB pathways. Int. J. Mol. Med. 2015, 36, 449-454. [CrossRef] [PubMed]

92. Campbell, I.G.; Freemont, P.S.; Foulkes, W.; Trowsdale, J. An ovarian tumor marker with homology to vaccinia virus contains an IgV-like region and multiple transmembrane domains. Cancer Res. 1992, 52, 5416-5420. [PubMed]

93. Tsai, R.K.; Discher, D.E. Inhibition of "self" engulfment through deactivation of myosin-II at the phagocytic synapse between human cells. J. Cell Biol. 2008, 180, 989-1003. [CrossRef] [PubMed]

94. Jaiswal, S.; Jamieson, C.H.; Pang, W.W.; Park, C.Y.; Chao, M.P.; Majeti, R.; Traver, D.; van Rooijen, N.; Weissman, I.L. CD47 is upregulated on circulating hematopoietic stem cells and leukemia cells to avoid phagocytosis. Cell 2009, 138, 271-285. [CrossRef] [PubMed]

95. Majeti, R.; Chao, M.P.; Alizadeh, A.A.; Pang, W.W.; Jaiswal, S.; Gibbs, K.D., Jr.; van Rooijen, N.; Weissman, I.L. CD47 is an adverse prognostic factor and therapeutic antibody target on human acute myeloid leukemia stem cells. Cell 2009, 138, 286-299. [CrossRef] [PubMed]

96. Chanmee, T.; Ontong, P.; Konno, K.; Itano, N. Tumor-associated macrophages as major players in the tumor microenvironment. Cancers 2014, 6, 1670-1690. [CrossRef] [PubMed]

97. Beury, D.W.; Parker, K.H.; Nyandjo, M.; Sinha, P.; Carter, K.A.; Ostrand-Rosenberg, S. Cross-talk among myeloid-derived suppressor cells, macrophages, and tumor cells impacts the inflammatory milieu of solid tumors. J. Leukoc. Biol. 2014, 96, 1109-1118. [CrossRef] [PubMed]

98. Topfer, K.; Kempe, S.; Muller, N.; Schmitz, M.; Bachmann, M.; Cartellieri, M.; Schackert, G.; Temme, A. Tumor evasion from T cell surveillance. J. Biomed. Biotechnol. 2011, 2011, 918471. [CrossRef] [PubMed]

99. Waldhauer, I.; Steinle, A. NK cells and cancer immunosurveillance. Oncogene 2008, 27, 5932-5943. [CrossRef] [PubMed] 
100. Swann, J.B.; Smyth, M.J. Immune surveillance of tumors. J. Clin. Investig. 2007, 117, 1137-1146. [CrossRef] [PubMed]

101. Squadrito, M.L.; Pucci, F.; Magri, L.; Moi, D.; Gilfillan, G.D.; Ranghetti, A.; Casazza, A.; Mazzone, M.; Lyle, R.; Naldini, L.; et al. miR-511-3p modulates genetic programs of tumor-associated macrophages. Cell Rep. 2012, 1, 141-154. [CrossRef] [PubMed]

102. Doedens, A.L.; Stockmann, C.; Rubinstein, M.P.; Liao, D.; Zhang, N.; DeNardo, D.G.; Coussens, L.M.; Karin, M.; Goldrath, A.W.; Johnson, R.S. Macrophage expression of hypoxia-inducible factor-1 alpha suppresses T-cell function and promotes tumor progression. Cancer Res. 2010, 70, 7465-7475. [CrossRef] [PubMed]

103. Lu, T.; Gabrilovich, D.I. Molecular pathways: Tumor-infiltrating myeloid cells and reactive oxygen species in regulation of tumor microenvironment. Clin. Cancer Res. 2012, 18, 4877-4882. [CrossRef] [PubMed]

104. Lu, T.; Ramakrishnan, R.; Altiok, S.; Youn, J.I.; Cheng, P.; Celis, E.; Pisarev, V.; Sherman, S.; Sporn, M.B.; Gabrilovich, D. Tumor-infiltrating myeloid cells induce tumor cell resistance to cytotoxic T cells in mice. J. Clin. Investig. 2011, 121, 4015-4029. [CrossRef] [PubMed]

105. Franklin, R.A.; Liao, W.; Sarkar, A.; Kim, M.V.; Bivona, M.R.; Liu, K.; Pamer, E.G.; Li, M.O. The cellular and molecular origin of tumor-associated macrophages. Science 2014, 344, 921-925. [CrossRef] [PubMed]

106. Su, S.; Liu, Q.; Chen, J.; Chen, J.; Chen, F.; He, C.; Huang, D.; Wu, W.; Lin, L.; Huang, W.; et al. A positive feedback loop between mesenchymal-like cancer cells and macrophages is essential to breast cancer metastasis. Cancer Cell 2014, 25, 605-620. [CrossRef] [PubMed]

107. Jeong, S.K.; Kim, J.S.; Lee, C.G.; Park, Y.S.; Kim, S.D.; Yoon, S.O.; Han, D.H.; Lee, K.Y.; Jeong, M.H.; Jo, W.S. Tumor associated macrophages provide the survival resistance of tumor cells to hypoxic microenvironmental condition through IL-6 receptor-mediated signals. Immunobiology 2017, 222, 55-65. [CrossRef] [PubMed]

108. Wang, R.; Zhang, J.; Chen, S.; Lu, M.; Luo, X.; Yao, S.; Liu, S.; Qin, Y.; Chen, H. Tumor-associated macrophages provide a suitable microenvironment for non-small lung cancer invasion and progression. Lung Cancer 2011, 74, 188-196. [CrossRef] [PubMed]

109. Almand, B.; Clark, J.I.; Nikitina, E.; van Beynen, J.; English, N.R.; Knight, S.C.; Carbone, D.P.; Gabrilovich, D.I. Increased production of immature myeloid cells in cancer patients: A mechanism of immunosuppression in cancer. J. Immunol. 2001, 166, 678-689. [CrossRef] [PubMed]

110. Talmadge, J.E.; Gabrilovich, D.I. History of myeloid-derived suppressor cells. Nat. Rev. Cancer 2013, 13, 739-752. [CrossRef] [PubMed]

111. Condamine, T.; Mastio, J.; Gabrilovich, D.I. Transcriptional regulation of myeloid-derived suppressor cells. J. Leukoc. Biol. 2015, 98, 913-922. [CrossRef] [PubMed]

112. Filipazzi, P.; Huber, V.; Rivoltini, L. Phenotype, function and clinical implications of myeloid-derived suppressor cells in cancer patients. Cancer Immunol. Immunother. CII 2012, 61, 255-263. [CrossRef] [PubMed]

113. Gabrilovich, D.I.; Ostrand-Rosenberg, S.; Bronte, V. Coordinated regulation of myeloid cells by tumours. Nat. Rev. Immunol. 2012, 12, 253-268. [CrossRef] [PubMed]

114. Nagaraj, S.; Gabrilovich, D.I. Tumor escape mechanism governed by myeloid-derived suppressor cells. Cancer Res. 2008, 68, 2561-2563. [CrossRef] [PubMed]

115. Nagaraj, S.; Youn, J.I.; Gabrilovich, D.I. Reciprocal relationship between myeloid-derived suppressor cells and T cells. J. Immunol. 2013, 191, 17-23. [CrossRef] [PubMed]

116. Hanson, E.M.; Clements, V.K.; Sinha, P.; Ilkovitch, D.; Ostrand-Rosenberg, S. Myeloid-derived suppressor cells down-regulate L-selectin expression on CD4+ and CD8+ T cells. J. Immunol. 2009, 183, 937-944. [CrossRef] [PubMed]

117. Wang, L.; Zhao, J.; Ren, J.P.; Wu, X.Y.; Morrison, Z.D.; Elgazzar, M.A.; Ning, S.B.; Moorman, J.P.; Yao, Z.Q. Expansion of myeloid-derived suppressor cells promotes differentiation of regulatory T cells in HIV-1+ individuals. Aids 2016, 30, 1521-1531. [CrossRef] [PubMed]

118. Zhu, J.; Huang, X.; Yang, Y. Myeloid-derived suppressor cells regulate natural killer cell response to adenovirus-mediated gene transfer. J. Virol. 2012, 86, 13689-13696. [CrossRef] [PubMed]

119. Hoechst, B.; Voigtlaender, T.; Ormandy, L.; Gamrekelashvili, J.; Zhao, F.; Wedemeyer, H.; Lehner, F.; Manns, M.P.; Greten, T.F.; Korangy, F. Myeloid derived suppressor cells inhibit natural killer cells in patients with hepatocellular carcinoma via the NKp30 receptor. Hepatology 2009, 50, 799-807. [CrossRef] [PubMed]

120. Sinha, P.; Clements, V.K.; Bunt, S.K.; Albelda, S.M.; Ostrand-Rosenberg, S. Cross-talk between myeloid-derived suppressor cells and macrophages subverts tumor immunity toward a type 2 response. J. Immunol. 2007, 179, 977-983. [CrossRef] [PubMed] 
121. Yu, J.; Du, W.; Yan, F.; Wang, Y.; Li, H.; Cao, S.; Yu, W.; Shen, C.; Liu, J.; Ren, X. Myeloid-derived suppressor cells suppress antitumor immune responses through IDO expression and correlate with lymph node metastasis in patients with breast cancer. J. Immunol. 2013, 190, 3783-3797. [CrossRef] [PubMed]

122. Qian, B.Z.; Li, J.; Zhang, H.; Kitamura, T.; Zhang, J.; Campion, L.R.; Kaiser, E.A.; Snyder, L.A.; Pollard, J.W. CCL2 recruits inflammatory monocytes to facilitate breast-tumour metastasis. Nature 2011, 475, 222-225. [CrossRef] [PubMed]

123. Kitamura, T.; Qian, B.Z.; Soong, D.; Cassetta, L.; Noy, R.; Sugano, G.; Kato, Y.; Li, J.; Pollard, J.W. CCL2-induced chemokine cascade promotes breast cancer metastasis by enhancing retention of metastasis-associated macrophages. J. Exp. Med. 2015, 212, 1043-1059. [CrossRef] [PubMed]

124. Ortiz, M.L.; Lu, L.; Ramachandran, I.; Gabrilovich, D.I. Myeloid-derived suppressor cells in the development of lung cancer. Cancer Immunol. Res. 2014, 2, 50-58. [CrossRef] [PubMed]

125. Corzo, C.A.; Condamine, T.; Lu, L.; Cotter, M.J.; Youn, J.I.; Cheng, P.; Cho, H.I.; Celis, E.; Quiceno, D.G.; Padhya, T; et al. HIF-1alpha regulates function and differentiation of myeloid-derived suppressor cells in the tumor microenvironment. J. Exp. Med. 2010, 207, 2439-2453. [CrossRef] [PubMed]

126. Kerkar, S.P.; Goldszmid, R.S.; Muranski, P.; Chinnasamy, D.; Yu, Z.; Reger, R.N.; Leonardi, A.J.; Morgan, R.A.; Wang, E.; Marincola, F.M.; et al. IL-12 triggers a programmatic change in dysfunctional myeloid-derived cells within mouse tumors. J. Clin. Investig. 2011, 121, 4746-4757. [CrossRef] [PubMed]

127. Xue, H.; Hua, L.M.; Guo, M.; Luo, J.M. SHIP1 is targeted by miR-155 in acute myeloid leukemia. Oncol. Rep. 2014, 32, 2253-2259. [CrossRef] [PubMed]

128. Taganov, K.D.; Boldin, M.P.; Chang, K.J.; Baltimore, D. NF-kappaB-dependent induction of microRNA miR-146, an inhibitor targeted to signaling proteins of innate immune responses. Proc. Natl. Acad. Sci. USA 2006, 103, 12481-12486. [CrossRef] [PubMed]

129. Chen, S.; Wang, L.; Fan, J.; Ye, C.; Dominguez, D.; Zhang, Y.; Curiel, T.J.; Fang, D.; Kuzel, T.M.; Zhang, B. Host miR155 promotes tumor growth through a myeloid-derived suppressor cell-dependent mechanism. Cancer Res. 2015, 75, 519-531. [CrossRef] [PubMed]

130. Cantoni, C.; Cignarella, F.; Ghezzi, L.; Mikesell, B.; Bollman, B.; Berrien-Elliott, M.M.; Ireland, A.R.; Fehniger, T.A.; Wu, G.F.; Piccio, L. Mir-223 regulates the number and function of myeloid-derived suppressor cells in multiple sclerosis and experimental autoimmune encephalomyelitis. Acta Neuropathol. 2017, 133, 61-77. [CrossRef] [PubMed]

131. Allavena, P.; Garlanda, C.; Borrello, M.G.; Sica, A.; Mantovani, A. Pathways connecting inflammation and cancer. Curr. Opin. Genet. Dev. 2008, 18, 3-10. [CrossRef] [PubMed]

132. Johnnidis, J.B.; Harris, M.H.; Wheeler, R.T.; Stehling-Sun, S.; Lam, M.H.; Kirak, O.; Brummelkamp, T.R.; Fleming, M.D.; Camargo, F.D. Regulation of progenitor cell proliferation and granulocyte function by microRNA-223. Nature 2008, 451, 1125-1129. [CrossRef] [PubMed]

133. Liu, Q.; Zhang, M.; Jiang, X.; Zhang, Z.; Dai, L.; Min, S.; Wu, X.; He, Q.; Liu, J.; Zhang, Y.; et al. miR-223 suppresses differentiation of tumor-induced $\mathrm{CD} 11 \mathrm{~b}(+) \mathrm{Gr} 1(+)$ myeloid-derived suppressor cells from bone marrow cells. Int. J. Cancer 2011, 129, 2662-2673. [CrossRef] [PubMed]

134. Lu, Z.; Liu, M.; Stribinskis, V.; Klinge, C.M.; Ramos, K.S.; Colburn, N.H.; Li, Y. MicroRNA-21 promotes cell transformation by targeting the programmed cell death 4 gene. Oncogene 2008, 27, 4373-4379. [CrossRef] [PubMed]

135. Hegde, V.L.; Tomar, S.; Jackson, A.; Rao, R.; Yang, X.; Singh, U.P.; Singh, N.P.; Nagarkatti, P.S.; Nagarkatti, M. Distinct microRNA expression profile and targeted biological pathways in functional myeloid-derived suppressor cells induced by Delta9-tetrahydrocannabinol in vivo: Regulation of CCAAT/enhancer-binding protein alpha by microRNA-690. J. Biol. Chem. 2013, 288, 36810-36826. [CrossRef] [PubMed]

136. Colotta, F.; Allavena, P.; Sica, A.; Garlanda, C.; Mantovani, A. Cancer-related inflammation, the seventh hallmark of cancer: Links to genetic instability. Carcinogenesis 2009, 30, 1073-1081. [CrossRef] [PubMed]

137. Crusz, S.M.; Balkwill, F.R. Inflammation and cancer: Advances and new agents. Nat. Rev. Clin. Oncol. 2015, 12, 584-596. [CrossRef] [PubMed]

138. Solinas, G.; Germano, G.; Mantovani, A.; Allavena, P. Tumor-associated macrophages (TAM) as major players of the cancer-related inflammation. J. Leukoc. Biol. 2009, 86, 1065-1073. [CrossRef] [PubMed]

139. Igaz, I.; Igaz, P. Are Circulating microRNAs Involved in Tumor Surveillance? In Circulating microRNAs in Disease Diagnostics and Their Potential Biological Relevance; Springer: Basel, Switzerland, 2015; Volume 106, pp. 269-280. [CrossRef] [PubMed] 
140. Nandi, B.; Shapiro, M.; Samur, M.K.; Pai, C.; Frank, N.Y.; Yoon, C.; Prabhala, R.H.; Munshi, N.C.; Gold, J.S. Stromal CCR6 drives tumor growth in a murine transplantable colon cancer through recruitment of tumor-promoting macrophages. Oncoimmunology 2016, 5, e1189052. [CrossRef] [PubMed]

141. Wang, G.; Lu, X.; Dey, P.; Deng, P.; Wu, C.C.; Jiang, S.; Fang, Z.; Zhao, K.; Konaparthi, R.; Hua, S.; et al. Targeting YAP-Dependent MDSC Infiltration Impairs Tumor Progression. Cancer Discov. 2016, 6, 80-95. [CrossRef] [PubMed]

142. Wang, J.; Jia, Y.; Wang, N.; Zhang, X.; Tan, B.; Zhang, G.; Cheng, Y. The clinical significance of tumor-infiltrating neutrophils and neutrophil-to-CD8+ lymphocyte ratio in patients with resectable esophageal squamous cell carcinoma. J. Transl. Med. 2014, 12, 7. [CrossRef] [PubMed]

143. Wu, X.; Zou, Y.; He, X.; Yuan, R.; Chen, Y.; Lan, N.; Lian, L.; Wang, F.; Fan, X.; Zeng, Y.; et al. Tumor-infiltrating mast cells in colorectal cancer as a poor prognostic factor. Int. J. Surg. Pathol. 2013, 21, 111-120. [CrossRef] [PubMed]

144. Fu, H.; Zhu, Y.; Wang, Y.; Liu, Z.; Zhang, J.; Wang, Z.; Xie, H.; Dai, B.; Xu, J.; Ye, D. Tumor Infiltrating Mast Cells (TIMs) Confers a Marked Survival Advantage in Nonmetastatic Clear-Cell Renal Cell Carcinoma. Ann. Surg. Oncol. 2017, 24, 1435-1442. [CrossRef] [PubMed]

145. Renzi, T.A.; Rubino, M.; Gornati, L.; Garlanda, C.; Locati, M.; Curtale, G. MiR-146b Mediates Endotoxin Tolerance in Human Phagocytes. Mediat. Inflamm. 2015, 2015, 145305. [CrossRef] [PubMed]

146. Bunt, S.K.; Yang, L.; Sinha, P.; Clements, V.K.; Leips, J.; Ostrand-Rosenberg, S. Reduced inflammation in the tumor microenvironment delays the accumulation of myeloid-derived suppressor cells and limits tumor progression. Cancer Res. 2007, 67, 10019-10026. [CrossRef] [PubMed]

147. Kim, K.J.; Wen, X.Y.; Yang, H.K.; Kim, W.H.; Kang, G.H. Prognostic Implication of M2 Macrophages Are Determined by the Proportional Balance of Tumor Associated Macrophages and Tumor Infiltrating Lymphocytes in Microsatellite-Unstable Gastric Carcinoma. PLoS ONE 2015, 10, e0144192. [CrossRef] [PubMed]

148. Karin, M.; Greten, F.R. NF-kappaB: Linking inflammation and immunity to cancer development and progression. Nat. Rev. Immunol. 2005, 5, 749-759. [CrossRef] [PubMed]

149. Karin, M. Nuclear factor-kappaB in cancer development and progression. Nature 2006, 441, 431-436. [CrossRef] [PubMed]

150. Pikarsky, E.; Porat, R.M.; Stein, I.; Abramovitch, R.; Amit, S.; Kasem, S.; Gutkovich-Pyest, E.; Urieli-Shoval, S.; Galun, E.; Ben-Neriah, Y. NF-kappaB functions as a tumour promoter in inflammation-associated cancer. Nature 2004, 431, 461-466. [CrossRef] [PubMed]

151. Yu, H.; Kortylewski, M.; Pardoll, D. Crosstalk between cancer and immune cells: Role of STAT3 in the tumour microenvironment. Nat. Rev. Immunol. 2007, 7, 41-51. [CrossRef] [PubMed]

152. Kortylewski, M.; Yu, H. Role of Stat3 in suppressing anti-tumor immunity. Curr. Opin. Immunol. 2008, 20, $228-233$. [CrossRef] [PubMed]

153. Wang, T.; Niu, G.; Kortylewski, M.; Burdelya, L.; Shain, K.; Zhang, S.; Bhattacharya, R.; Gabrilovich, D.; Heller, R.; Coppola, D.; et al. Regulation of the innate and adaptive immune responses by Stat-3 signaling in tumor cells. Nat. Med. 2004, 10, 48-54. [CrossRef] [PubMed]

154. Bazzoni, F.; Rossato, M.; Fabbri, M.; Gaudiosi, D.; Mirolo, M.; Mori, L.; Tamassia, N.; Mantovani, A.; Cassatella, M.A.; Locati, M. Induction and regulatory function of miR-9 in human monocytes and neutrophils exposed to proinflammatory signals. Proc. Natl. Acad. Sci. USA 2009, 106, 5282-5287. [CrossRef] [PubMed]

155. Huang, S.; DeGuzman, A.; Bucana, C.D.; Fidler, I.J. Nuclear factor-kappaB activity correlates with growth, angiogenesis, and metastasis of human melanoma cells in nude mice. Clin. Cancer Res. 2000, 6, 2573-2581. [PubMed]

156. Cekaite, L.; Rantala, J.K.; Bruun, J.; Guriby, M.; Agesen, T.H.; Danielsen, S.A.; Lind, G.E.; Nesbakken, A.; Kallioniemi, O.; Lothe, R.A.; et al. MiR-9, -31, and -182 deregulation promote proliferation and tumor cell survival in colon cancer. Neoplasia 2012, 14, 868-879. [CrossRef] [PubMed]

157. Yang, M.; Chen, J.; Su, F.; Yu, B.; Su, F.; Lin, L.; Liu, Y.; Huang, J.D.; Song, E. Microvesicles secreted by macrophages shuttle invasion-potentiating microRNAs into breast cancer cells. Mol. Cancer 2011, 10, 117. [CrossRef] [PubMed]

158. Brasier, A.R. The nuclear factor-kappaB-interleukin-6 signalling pathway mediating vascular inflammation. Cardiovasc. Res. 2010, 86, 211-218. [CrossRef] [PubMed] 
159. Takano, Y.; Masuda, T.; Iinuma, H.; Yamaguchi, R.; Sato, K.; Tobo, T.; Hirata, H.; Kuroda, Y.; Nambara, S.; Hayashi, N.; et al. Circulating exosomal microRNA-203 is associated with metastasis possibly via inducing tumor-associated macrophages in colorectal cancer. Oncotarget 2017, 8, 78598-78613. [CrossRef] [PubMed]

160. Zheng, P.; Chen, L.; Yuan, X.; Luo, Q.; Liu, Y.; Xie, G.; Ma, Y.; Shen, L. Exosomal transfer of tumor-associated macrophage-derived miR-21 confers cisplatin resistance in gastric cancer cells. J. Exp. Clin. Cancer Res. CR 2017, 36, 53. [CrossRef] [PubMed]

161. Patel, S.A.; Gooderham, N.J. IL6 Mediates Immune and Colorectal Cancer Cell Cross-talk via miR-21 and miR-29b. Mol. Cancer Res. MCR 2015, 13, 1502-1508. [CrossRef] [PubMed]

162. Curtale, G.; Renzi, T.A.; Drufuca, L.; Rubino, M.; Locati, M. Glucocorticoids downregulate TLR4 signaling activity via its direct targeting by miR-511-5p. Eur. J. Immunol. 2017, 47, 2080-2089. [CrossRef] [PubMed]

163. Rossato, M.; Curtale, G.; Tamassia, N.; Castellucci, M.; Mori, L.; Gasperini, S.; Mariotti, B.; De Luca, M.; Mirolo, M.; Cassatella, M.A.; et al. IL-10-induced microRNA-187 negatively regulates TNF-alpha, IL-6, and IL-12p40 production in TLR4-stimulated monocytes. Proc. Natl. Acad. Sci. USA 2012, 109, E3101-E3110. [CrossRef] [PubMed]

164. Androulidaki, A.; Iliopoulos, D.; Arranz, A.; Doxaki, C.; Schworer, S.; Zacharioudaki, V.; Margioris, A.N.; Tsichlis, P.N.; Tsatsanis, C. The kinase Akt1 controls macrophage response to lipopolysaccharide by regulating microRNAs. Immunity 2009, 31, 220-231. [CrossRef] [PubMed]

165. Lai, L.; Song, Y.; Liu, Y.; Chen, Q.; Han, Q.; Chen, W.; Pan, T.; Zhang, Y.; Cao, X.; Wang, Q. MicroRNA-92a negatively regulates Toll-like receptor (TLR)-triggered inflammatory response in macrophages by targeting MKK4 kinase. J. Biol. Chem. 2013, 288, 7956-7967. [CrossRef] [PubMed]

166. Yu, H.; Liu, Y.; McFarland, B.C.; Deshane, J.S.; Hurst, D.R.; Ponnazhagan, S.; Benveniste, E.N.; Qin, H. SOCS3 Deficiency in Myeloid Cells Promotes Tumor Development: Involvement of STAT3 Activation and Myeloid-Derived Suppressor Cells. Cancer Immunol. Res. 2015, 3, 727-740. [CrossRef] [PubMed]

167. Kujawski, M.; Kortylewski, M.; Lee, H.; Herrmann, A.; Kay, H.; Yu, H. Stat3 mediates myeloid cell-dependent tumor angiogenesis in mice. J. Clin. Investig. 2008, 118, 3367-3377. [CrossRef] [PubMed]

168. Zhang, M.; Liu, Q.; Mi, S.; Liang, X.; Zhang, Z.; Su, X.; Liu, J.; Chen, Y.; Wang, M.; Zhang, Y.; et al. Both miR-17-5p and miR-20a alleviate suppressive potential of myeloid-derived suppressor cells by modulating STAT3 expression. J. Immunol. 2011, 186, 4716-4724. [CrossRef] [PubMed]

169. Zhou, W.; Fong, M.Y.; Min, Y.; Somlo, G.; Liu, L.; Palomares, M.R.; Yu, Y.; Chow, A.; O'Connor, S.T.; Chin, A.R.; et al. Cancer-secreted miR-105 destroys vascular endothelial barriers to promote metastasis. Cancer Cell 2014, 25, 501-515. [CrossRef] [PubMed]

170. Derynck, R.; Akhurst, R.J.; Balmain, A. TGF-beta signaling in tumor suppression and cancer progression. Nat. Genet. 2001, 29, 117-129. [CrossRef] [PubMed]

171. Padua, D.; Massague, J. Roles of TGFbeta in metastasis. Cell Res. 2009, 19, 89-102. [CrossRef] [PubMed]

172. Seoane, J.; Gomis, R.R. TGF-beta Family Signaling in Tumor Suppression and Cancer Progression. Cold Spring Harb. Perspect. Biol. 2017, 9, a022277. [CrossRef] [PubMed]

173. Soon, P.; Kiaris, H. MicroRNAs in the tumour microenvironment: Big role for small players. Endocr.-Relat. Cancer 2013, 20, R257-R267. [CrossRef] [PubMed]

174. Chen, X.; Ying, X.; Wang, X.; Wu, X.; Zhu, Q.; Wang, X. Exosomes derived from hypoxic epithelial ovarian cancer deliver microRNA-940 to induce macrophage M2 polarization. Oncol. Rep. 2017, 38, 522-528. [CrossRef] [PubMed]

175. Imaoka, H.; Toiyama, Y.; Okigami, M.; Yasuda, H.; Saigusa, S.; Ohi, M.; Tanaka, K.; Inoue, Y.; Mohri, Y.; Kusunoki, M. Circulating microRNA-203 predicts metastases, early recurrence, and poor prognosis in human gastric cancer. Gastric Cancer Off. J. Int. Gastric Cancer Assoc. Jpn. Gastric Cancer Assoc. 2016, 19, 744-753. [CrossRef] [PubMed]

176. Hur, K.; Toiyama, Y.; Okugawa, Y.; Ide, S.; Imaoka, H.; Boland, C.R.; Goel, A. Circulating microRNA-203 predicts prognosis and metastasis in human colorectal cancer. Gut 2017, 66, 654-665. [CrossRef] [PubMed]

177. Rask, L.; Balslev, E.; Jorgensen, S.; Eriksen, J.; Flyger, H.; Moller, S.; Hogdall, E.; Litman, T.; Nielsen, B.S. High expression of miR-21 in tumor stroma correlates with increased cancer cell proliferation in human breast cancer. APMIS: Acta Pathol. Microbiol. Immunol. Scand. 2011, 119, 663-673. [CrossRef] [PubMed]

178. Yan, L.X.; Wu, Q.N.; Zhang, Y.; Li, Y.Y.; Liao, D.Z.; Hou, J.H.; Fu, J.; Zeng, M.S.; Yun, J.P.; Wu, Q.L.; et al. Knockdown of miR-21 in human breast cancer cell lines inhibits proliferation, in vitro migration and in vivo tumor growth. Breast Cancer Res. BCR 2011, 13, R2. [CrossRef] [PubMed] 
179. Waldner, M.J.; Foersch, S.; Neurath, M.F. Interleukin-6-A key regulator of colorectal cancer development. Int. J. Biol. Sci. 2012, 8, 1248-1253. [CrossRef] [PubMed]

180. Nagasaki, T.; Hara, M.; Nakanishi, H.; Takahashi, H.; Sato, M.; Takeyama, H. Interleukin-6 released by colon cancer-associated fibroblasts is critical for tumour angiogenesis: Anti-interleukin- 6 receptor antibody suppressed angiogenesis and inhibited tumour-stroma interaction. Br. J. Cancer 2014, 110, 469-478. [CrossRef] [PubMed]

181. Zhuang, G.; Wu, X.; Jiang, Z.; Kasman, I.; Yao, J.; Guan, Y.; Oeh, J.; Modrusan, Z.; Bais, C.; Sampath, D.; et al. Tumour-secreted miR-9 promotes endothelial cell migration and angiogenesis by activating the JAK-STAT pathway. EMBO J. 2012, 31, 3513-3523. [CrossRef] [PubMed]

182. Wang, N.; Chen, C.; Yang, D.; Liao, Q.; Luo, H.; Wang, X.; Zhou, F.; Yang, X.; Yang, J.; Zeng, C.; et al. Mesenchymal stem cells-derived extracellular vesicles, via miR-210, improve infarcted cardiac function by promotion of angiogenesis. Biochim. Biophys. Acta 2017, 1863, 2085-2092. [CrossRef] [PubMed]

183. Le, M.T.; Hamar, P.; Guo, C.; Basar, E.; Perdigao-Henriques, R.; Balaj, L.; Lieberman, J. miR-200-containing extracellular vesicles promote breast cancer cell metastasis. J. Clin. Investig. 2014, 124, 5109-5128. [CrossRef] [PubMed]

184. Kobayashi, M.; Salomon, C.; Tapia, J.; Illanes, S.E.; Mitchell, M.D.; Rice, G.E. Ovarian cancer cell invasiveness is associated with discordant exosomal sequestration of Let-7 miRNA and miR-200. J. Transl. Med. 2014, 12, 4. [CrossRef] [PubMed]

185. Epstein, D.M. Special delivery: MicroRNA-200-containing extracellular vesicles provide metastatic message to distal tumor cells. J. Clin. Investig. 2014, 124, 5107-5108. [CrossRef] [PubMed]

186. Kanlikilicer, P.; Rashed, M.H.; Bayraktar, R.; Mitra, R.; Ivan, C.; Aslan, B.; Zhang, X.; Filant, J.; Silva, A.M.; Rodriguez-Aguayo, C.; et al. Ubiquitous Release of Exosomal Tumor Suppressor miR-6126 from Ovarian Cancer Cells. Cancer Res. 2016, 76, 7194-7207. [CrossRef] [PubMed]

187. Qattan, A.; Intabli, H.; Alkhayal, W.; Eltabache, C.; Tweigieri, T.; Amer, S.B. Robust expression of tumor suppressor miRNA's let-7 and miR-195 detected in plasma of Saudi female breast cancer patients. BMC Cancer 2017, 17, 799. [CrossRef] [PubMed]

188. Feng, Y.; Kang, Y.; He, Y.; Liu, J.; Liang, B.; Yang, P.; Yu, Z. microRNA-99a acts as a tumor suppressor and is down-regulated in bladder cancer. BMC Urol. 2014, 14, 50. [CrossRef] [PubMed]

189. Ohshima, K.; Inoue, K.; Fujiwara, A.; Hatakeyama, K.; Kanto, K.; Watanabe, Y.; Muramatsu, K.; Fukuda, Y.; Ogura, S.; Yamaguchi, K.; et al. Let-7 microRNA family is selectively secreted into the extracellular environment via exosomes in a metastatic gastric cancer cell line. PLoS ONE 2010, 5, e13247. [CrossRef] [PubMed]

190. Goto, Y.; Nishikawa, R.; Kojima, S.; Chiyomaru, T.; Enokida, H.; Inoguchi, S.; Kinoshita, T.; Fuse, M.; Sakamoto, S.; Nakagawa, M.; et al. Tumour-suppressive microRNA-224 inhibits cancer cell migration and invasion via targeting oncogenic TPD52 in prostate cancer. FEBS Lett. 2014, 588, 1973-1982. [CrossRef] [PubMed]

191. Ostenfeld, M.S.; Jeppesen, D.K.; Laurberg, J.R.; Boysen, A.T.; Bramsen, J.B.; Primdal-Bengtson, B.; Hendrix, A.; Lamy, P.; Dagnaes-Hansen, F.; Rasmussen, M.H.; et al. Cellular disposal of miR23b by RAB27-dependent exosome release is linked to acquisition of metastatic properties. Cancer Res. 2014, 74, 5758-5771. [CrossRef] [PubMed]

192. Donadelli, M.; Dando, I.; Fiorini, C.; Palmieri, M. Regulation of miR-23b expression and its dual role on ROS production and tumour development. Cancer Lett. 2014, 349, 107-113. [CrossRef] [PubMed]

193. Igaz, I.; Igaz, P. Tumor surveillance by circulating microRNAs: A hypothesis. Cell. Mol. Life Sci. CMLS 2014, 71, 4081-4087. [CrossRef] [PubMed]

194. Dudek, A.M.; Garg, A.D.; Krysko, D.V.; De Ruysscher, D.; Agostinis, P. Inducers of immunogenic cancer cell death. Cytokine Growth Factor Rev. 2013, 24, 319-333. [CrossRef] [PubMed]

195. Vandenabeele, P.; Vandecasteele, K.; Bachert, C.; Krysko, O.; Krysko, D.V. Immunogenic Apoptotic Cell Death and Anticancer Immunity. Adv. Exp. Med. Biol. 2016, 930, 133-149. [CrossRef] [PubMed]

196. Colangelo, T.; Polcaro, G.; Ziccardi, P.; Muccillo, L.; Galgani, M.; Pucci, B.; Milone, M.R.; Budillon, A.; Santopaolo, M.; Mazzoccoli, G.; et al. The miR-27a-calreticulin axis affects drug-induced immunogenic cell death in human colorectal cancer cells. Cell Death Dis. 2016, 7, e2108. [CrossRef] [PubMed]

197. Alderton, G.K.; Bordon, Y. Tumour immunotherapy-Leukocytes take up the fight. Nat. Rev. Immunol. 2012, 12, 237. [CrossRef] [PubMed] 
198. Bird, L. Immunotherapy: Remote control CARs. Nat. Rev. Drug Discov. 2015, 14, 819. [CrossRef] [PubMed]

199. Pardoll, D.M. The blockade of immune checkpoints in cancer immunotherapy. Nat. Rev. Cancer 2012, 12, 252-264. [CrossRef] [PubMed]

200. Topalian, S.L.; Drake, C.G.; Pardoll, D.M. Immune checkpoint blockade: A common denominator approach to cancer therapy. Cancer Cell 2015, 27, 450-461. [CrossRef] [PubMed]

201. Tseng, D.; Volkmer, J.P.; Willingham, S.B.; Contreras-Trujillo, H.; Fathman, J.W.; Fernhoff, N.B.; Seita, J.; Inlay, M.A.; Weiskopf, K.; Miyanishi, M.; et al. Anti-CD47 antibody-mediated phagocytosis of cancer by macrophages primes an effective antitumor T-cell response. Proc. Natl. Acad. Sci. USA 2013, 110, 11103-11108. [CrossRef] [PubMed]

202. Iclozan, C.; Antonia, S.; Chiappori, A.; Chen, D.T.; Gabrilovich, D. Therapeutic regulation of myeloid-derived suppressor cells and immune response to cancer vaccine in patients with extensive stage small cell lung cancer. Cancer Immunol. Immunother. CII 2013, 62, 909-918. [CrossRef] [PubMed]

203. Dominguez, G.A.; Condamine, T.; Mony, S.; Hashimoto, A.; Wang, F.; Liu, Q.; Forero, A.; Bendell, J.; Witt, R.; Hockstein, N.; et al. Selective Targeting of Myeloid-Derived Suppressor Cells in Cancer Patients Using DS-8273a, an Agonistic TRAIL-R2 Antibody. Clin. Cancer Res. 2017, 23, 2942-2950. [CrossRef] [PubMed]

204. Gul, N.; Babes, L.; Siegmund, K.; Korthouwer, R.; Bogels, M.; Braster, R.; Vidarsson, G.; ten Hagen, T.L.; Kubes, P.; van Egmond, M. Macrophages eliminate circulating tumor cells after monoclonal antibody therapy. J. Clin. Investig. 2014, 124, 812-823. [CrossRef] [PubMed]

205. Dalmay, T.; Edwards, D.R. MicroRNAs and the hallmarks of cancer. Oncogene 2006, 25, 6170-6175. [CrossRef] [PubMed]

206. Ruan, K.; Fang, X.; Ouyang, G. MicroRNAs: Novel regulators in the hallmarks of human cancer. Cancer Lett. 2009, 285, 116-126. [CrossRef] [PubMed]

(C) 2018 by the author. Licensee MDPI, Basel, Switzerland. This article is an open access article distributed under the terms and conditions of the Creative Commons Attribution (CC BY) license (http:/ / creativecommons.org/licenses/by/4.0/). 